ARTICLE

Received 13 Aug 2015 | Accepted 24 Feb 2016 | Published 4 Apr 2016

DOI: $10.1038 /$ ncomms11148

OPEN

\title{
Evidence for ice-free summers in the late Miocene central Arctic Ocean
}

\author{
Ruediger Stein ${ }^{1,2}$, Kirsten Fahl', Michael Schreck ${ }^{3}$, Gregor Knorr ${ }^{1}$, Frank Niessen ${ }^{1}$, Matthias Forwick ${ }^{4}$, \\ Catalina Gebhardt', Laura Jensen ${ }^{1}$, Michael Kaminski ${ }^{5}$, Achim Kopf ${ }^{2}, 6$, Jens Matthiessen? \\ Wilfried Jokat ${ }^{1,2} \&$ Gerrit Lohmann ${ }^{1,6}$
}

\begin{abstract}
Although the permanently to seasonally ice-covered Arctic Ocean is a unique and sensitive component in the Earth's climate system, the knowledge of its long-term climate history remains very limited due to the restricted number of pre-Quaternary sedimentary records. During Polarstern Expedition PS87/2014, we discovered multiple submarine landslides along Lomonosov Ridge. Removal of younger sediments from steep headwalls has led to exhumation of Miocene sediments close to the seafloor. Here we document the presence of $\mathrm{IP}_{25}$ as a proxy for spring sea-ice cover and alkenone-based summer sea-surface temperatures $>4{ }^{\circ} \mathrm{C}$ that support a seasonal sea-ice cover with an ice-free summer season being predominant during the late Miocene in the central Arctic Ocean. A comparison of our proxy data with Miocene climate simulations seems to favour either relatively high late Miocene atmospheric $\mathrm{CO}_{2}$ concentrations and/or a weak sensitivity of the model to simulate the magnitude of high-latitude warming in a warmer than modern climate.
\end{abstract}

\footnotetext{
${ }^{1}$ Alfred Wegener Institute (AWI) Helmholtz Centre for Polar and Marine Research, Am Alten Hafen 26, Bremerhaven 27568, Germany. ${ }^{2}$ Department of Geosciences (FB5), University of Bremen, Klagenfurter Strasse 4, Bremen 28359, Germany. ${ }^{3}$ Arctic Research Centre, Korea Polar Research Institute, 26 Songdomirae-ro, Yeonsu-gu, Incheon 406-840, Korea. ${ }^{4}$ Institute of Geology, University of Tromsø-The Arctic University of Norway, P O Box 6050 Langnes, Tromsø 9037, Norway. ${ }^{5}$ Geosciences Department, College of Petroleum Engineering \& Geosciences, King Fahd University of Petroleum \& Minerals, Dhahran 31261, Saudi Arabia. ${ }^{6}$ MARUM-Center for Marine Environmental Sciences, University of Bremen, Leobener Strasse, Bremen 28359, Germany. Correspondence and requests for materials should be addressed to R.S. (email: Ruediger.Stein@awi.de).
} 
here is a general consensus that the polar regions-and in particular the Arctic Ocean and surrounding areas-are at present, and were over historic and geologic time scales, subject to rapid and dramatic environmental changes. Owing to complex feedback processes, collectively known as 'polar amplification', the Arctic is both a contributor to climate change and a region that will be most affected by global warming ${ }^{1-3}$. Despite the importance of the Arctic Ocean in the global climate
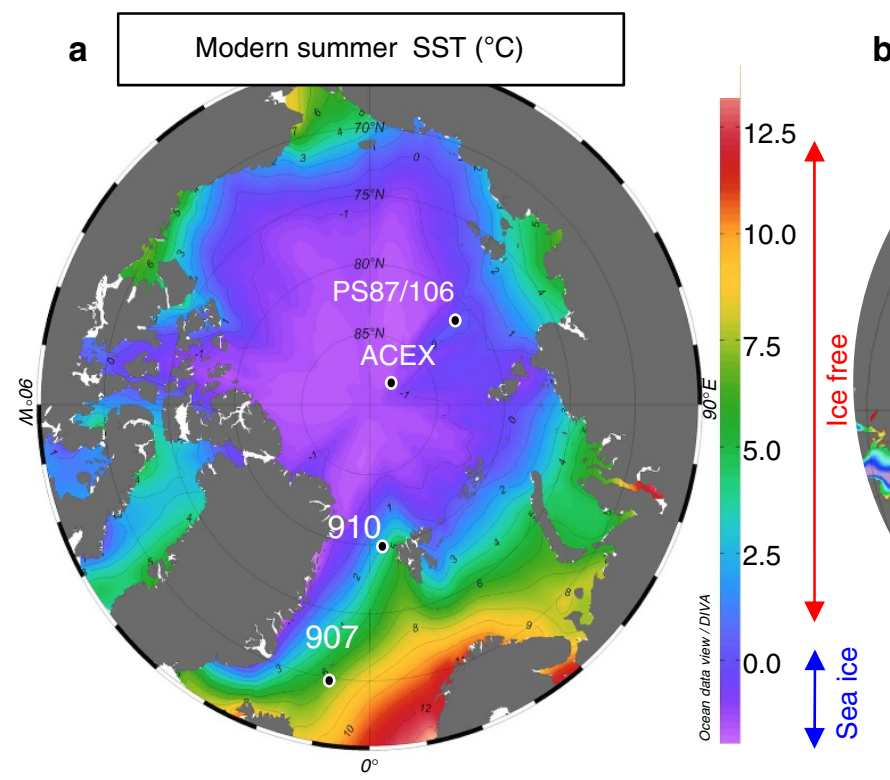

b

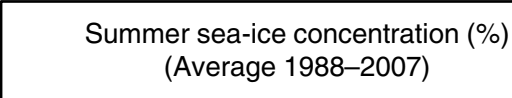

(Average 1988-2007)

C Arctic Ocean sea ice and related biogenic and terrigenous sediment fluxes

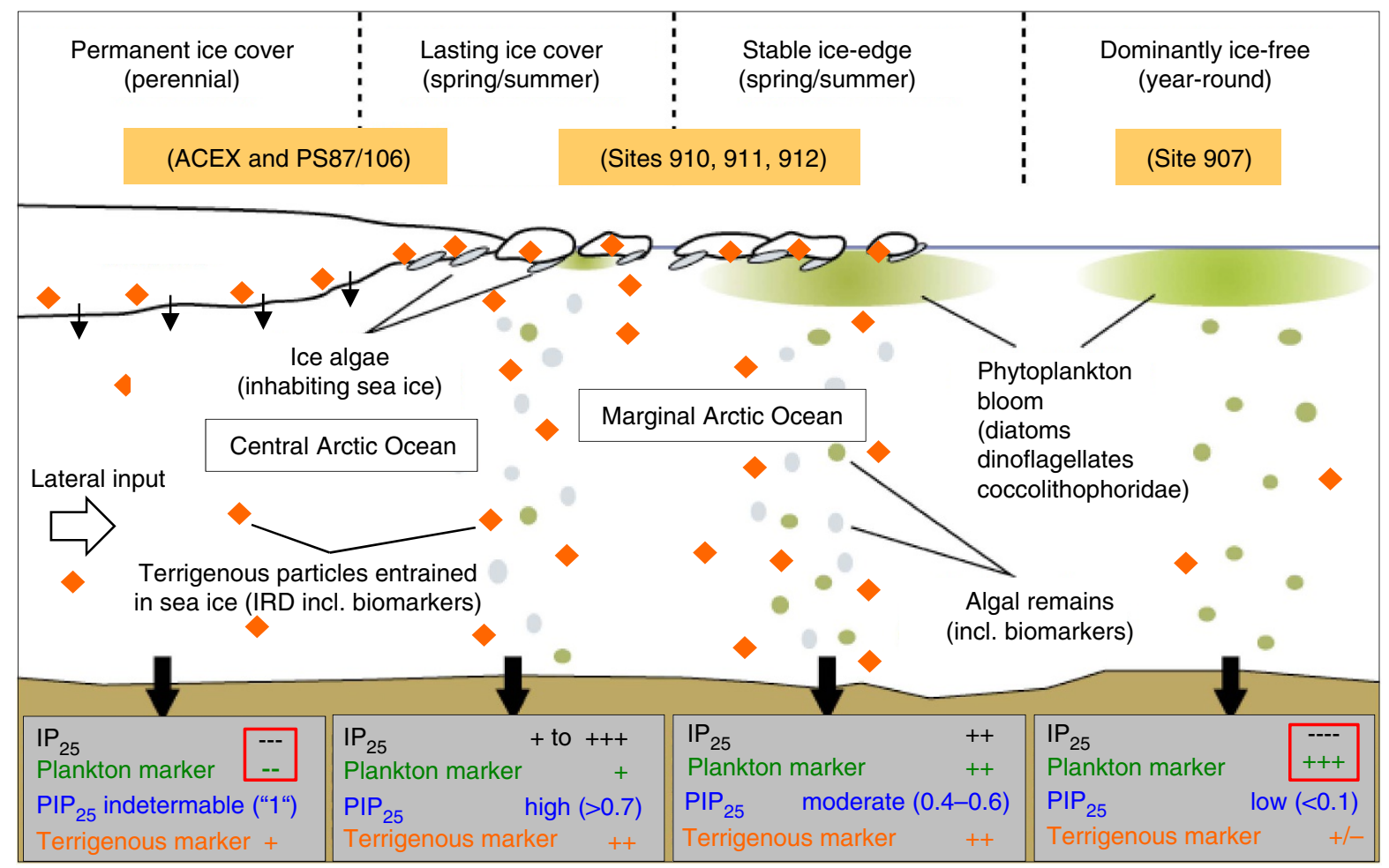

Figure 1 | Modern Arctic Ocean SST and sea-ice conditions. (a) Map of modern August SST with locations of ODP Site 907, ODP Site 910 and IODP Expedition 302 (ACEX) Site, as well as Core PS87/106 (August SST data-average of 1955-2012-from World Ocean Atlas; http://odv.awi.de/en/data/ ocean/world_ocean_atlas_2013/). (b) Map of summer sea-ice concentration-average of 1988-2007-with locations of studied sites (black dots); data source: http://nsidc.org. Maps a and b produced with Ocean Data View software (source: http://odv.awi.de/). (c) Generalized scheme illustrating (1) sea surface conditions and respective (spring/summer) productivities of ice algae and phytoplankton, and (2) sedimentary contents of IP 25 , terrigenous biomarkers and IRD, phytoplankton-derived biomarkers and $\mathrm{PIP}_{25}$ index for different settings in the modern Arctic Ocean (after ref. 14, supplemented). Owing to ice melting and related nutrient and sediment release, a stable ice-edge situation is characterized by high concentrations of $\mathrm{IP}_{25}$ and phytoplanktion biomarkers, but also by high concentrations of terrigenous biomarkers and IRD. Modern situations at locations of ACEX and PS87/106, ODP Site 910 (and close-by ODP sites 911 and 912) and ODP Site 907 are indicated. 
system, this permanently to seasonally ice-covered region (Fig. 1) is one of the last major physiographic provinces on Earth, whose climate history and its transition from early Cenozoic Greenhouse to late Cenozoic Icehouse conditions remain still poorly known. Only one drill site recovered from the central Arctic Ocean during the Arctic Coring Expedition (ACEX)-the Integrated Ocean Drilling Program (IODP) Expedition 302 in 2004 - gives some insight into the early Cenozoic climate ${ }^{4-6}$.

Concerning recent climate change, the most prominent example is the dramatic decrease of the extent and thickness of the Arctic sea-ice cover the last decades, a decrease that seems to be by far more rapid than predicted by climate models ${ }^{1,3}$. The scientific community recognized this drastic change with major concern as the Arctic sea ice is a critical component in the global climate system, which contributes to changes in the Earth's albedo, primary productivity and deep-water formation, a driving mechanism for global thermohaline circulation ${ }^{7}$. The causes of these recent changes, that is, natural versus anthropogenic forcings, and their relevance within the global climate system, however, are subject of intense scientific and societal debate. Thus, understanding the processes controlling Arctic sea-ice variability is of overall interest and significance ${ }^{8,9}$. In this context, records of past climate and sea-ice conditions going beyond instrumental records and representing times of different boundary conditions are of major value: such records can be used to assess the sensitivity of the Earth's climate system to changes of different forcing parameters, for example, level of $\mathrm{CO}_{2}$, and to test the reliability of climate models by evaluating their simulations for conditions very different from the modern climate. This type of records giving detailed information about past Arctic sea-ice conditions are still very rare, especially due to the lack of precise proxies for sea-ice reconstructions (see review in ref. 9).

The ability to (semi-)quantitatively reconstruct paleo-sea-ice distributions has been significantly improved by a biomarker approach based on the determination of a highly branched isoprenoid $(\mathrm{HBI})$ with 25 carbons $\left(\mathrm{C}_{25} \mathrm{HBI} \text { monoene }=\mathrm{IP}_{25}\right)^{10}$. This biomarker is only biosynthesized by specific diatoms living in the Arctic ice ${ }^{11}$ and appears to be a specific, sensitive and stable proxy for Arctic sea ice in sedimentary sections representing Pliocene to Pleistocene times ${ }^{12,13}$. When using this proxy, one has to consider that $\mathrm{IP}_{25}$ is absent under a permanent sea-ice cover limiting light penetration and, in consequence, sea-ice algal growth (that is, $\mathrm{IP}_{25}=0$ ). The same consequence applies to totally ice-free conditions (Fig. 1). Müller et al. ${ }^{14,15}$ overcame this difficulty in interpretating $\mathrm{IP}_{25}$ data by the additional use of phytoplankton-derived open-water biomarkers such as brassicasterol or dinosterol (Fig. 1). Furthermore, Müller et al. ${ }^{14}$ combined the environmental information carried by $\mathrm{IP}_{25}$ and phytoplankton biomarkers in a phytoplankton- $\mathrm{IP}_{25}$ index, the so-called 'PIP 25 index' (for calculation of PIP $_{25}$, see 'Methods'). In general, the $\mathrm{PIP}_{25}$ values determined in Arctic Ocean surface sediments correlate reasonably well with the modern sea-ice distribution based on satellite data, although regional differences in the correlation patterns seem to be obvious ${ }^{14,16}$. In the modern central Arctic Ocean characterized by a mostly perennial sea-ice cover, the $\mathrm{PIP}_{25}$ values of most of the surface sediments are between 0.65 and 1 (ref. 16). These data suggest that the $\mathrm{PIP}_{25}$ index seems to be a promising proxy for more semi-quantitative estimates of the present and past sea-ice extent, although certainly further groundtruth data are needed (see Methods for some more details) ${ }^{8,16}$.

Here we apply the new sea-ice biomarker approach together with alkenone-based sea-surface temperatures (SSTs) to sediment cores most recently recovered during Polarstern Expedition PS87 (ref. 17), to reconstruct upper Miocene Arctic Ocean sea-ice and SST conditions. The proxy data are combined with climate model simulations using a coupled atmosphere-ocean general circulation model (AOGCM; see Methods) with focus on seasonal changes in the high northern latitudes. Based on our new proxy records, we demonstrate that only a seasonal sea-ice cover has been predominant in the central Arctic Ocean during (most of) the Late Miocene time interval. Furthermore, our combined data/modelling approach seems to indicate either relatively high atmospheric $\mathrm{CO}_{2}$ concentrations and/or an overly weak sensitivity of the model to simulate the magnitude of warm polar temperatures in the late Miocene. These new findings from the Arctic region provide new benchmarks for groundtruthing global climate reconstructions and modelling.

\section{Results}

Large submarine slide scars along Lomonosov Ridge. Polarstern Expedition PS87 was scheduled for August-September 2014 to explore the Lomonosov Ridge area (Fig. 2) with the objective of collecting seismic data and sediment cores to reconstruct the short- and long-term climate history and the tectonic evolution of the central Arctic Ocean ${ }^{17}$. More than $3,000 \mathrm{~km}$ of high-quality multi-channel seismic (MCS) profiles and $\sim 10,000 \mathrm{~km}$ of high-quality multibeam bathymetry and sub-bottom sedimentechosounding (PARASOUND) profiles were acquired along the ship's track and numerous sediment cores were recovered (Fig. 2). One major finding of the expedition was the discovery of numerous submarine slide scars that occurred on both sides of the crest of Lomonosov Ridge over a distance of $c a .350 \mathrm{~km}$ between $81^{\circ} 07^{\prime} \mathrm{N}$ and $84^{\circ} 14^{\prime} \mathrm{N}$ in water depths from $\sim 800$ to $1,500 \mathrm{~m}$ (Fig. 3a). Single scars are up to several kilometres wide and long, and their head walls are $100-500 \mathrm{~m}$ high. Swath-bathymetry data indicate that different processes probably triggered slope failures, that various processes of sediment evacuation took place, and that failures occurred at various times. Slide scars were earlier described from a restricted area on Lomonosov Ridge near $88^{\circ} \mathrm{N}^{18}$. However, the wide lateral distribution of mass wasting as presented here is a new discovery.

On top of the southern Lomonosov Ridge in areas between the slide scars, we discovered SE-NW oriented, streamlined landforms over distances of $>100 \mathrm{~km}$ at water depths between 800 and $1,000 \mathrm{~m}$ (Fig. 3a). These features are interpreted to be glacial lineations that formed beneath grounded ice ${ }^{19,20}$. Similar unidirectional bed forms have also been identified further east on the East Siberian continental margin where they were related to large and coherent ice masses (East Siberian Chukchi Ice Sheet-ESCIS) ${ }^{21}$. The lineations identified in this study are similar to those on the East Siberian continental margin with respect to their orthogonal orientations to the proposed centre of the former ESCIS. At the present state of knowledge, the most plausible glacial scenario is a larger than originally proposed ESCIS including an ice shelf extending into the Arctic Ocean, which formed an ice rise on the Southern Lomonosov Ridge over areas presently shallower than $1,000 \mathrm{~m}$. The load and erosional behaviour of this ice rise that probably occurred during extended Quaternary glaciations, for example, during Marine Isotope Stage 6 (MIS 6), may have caused physical conditions that triggered the landslides on this part of Lomonosov Ridge. A MIS 6 age of this erosional event is in line with the proposed age of a major glaciation with extended ice sheets/shelves in Eurasia and East Siberia ${ }^{19-21}$.

Exhumation of Miocene to lower Quaternary sediments. Sediment removal from the steep slopes of the escarpments exposed older, normally more deeply buried deposits at/near the present seafloor, allowing retrieval of older sediments by gravity 


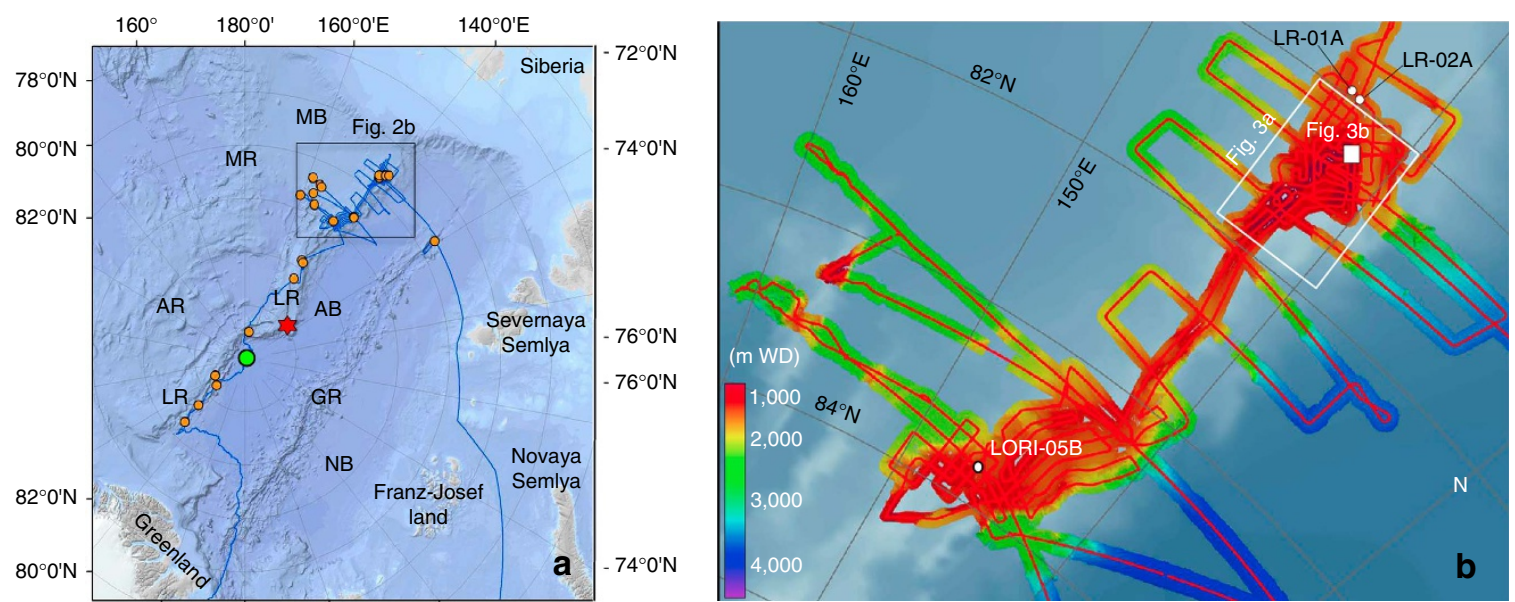

Figure 2 | Cruise track and multibeam bathymetric survey of Polarstern Expedition PS87. (a) PS87 cruise track (blue line) ${ }^{17}$. AB, Amundsen Basin; AR, Alpha Ridge; GR, Gakkel Ridge; LR, Lomonosov Ridge; MB, Makarov Basin; MR, Mendeleev Ridge; NB, Nansen Basin. Orange circles indicate coring stations, the red asterisk indicates the location of the ACEX Site and the green circle indicates the North Pole (Polarstern reached on 26 August 2014 at 10:23 UTC). (b) Track lines of multibeam bathymetric survey. Colour bar indicates water depth in metres (m WD). LR-01A, LR-02A and LORI-05B indicate locations of proposed IODP drill sites ${ }^{51}$ (cf., IODP Proposal 708; http://www.iodp.org/expeditions). Areas of Fig. 3a,b are indicated.

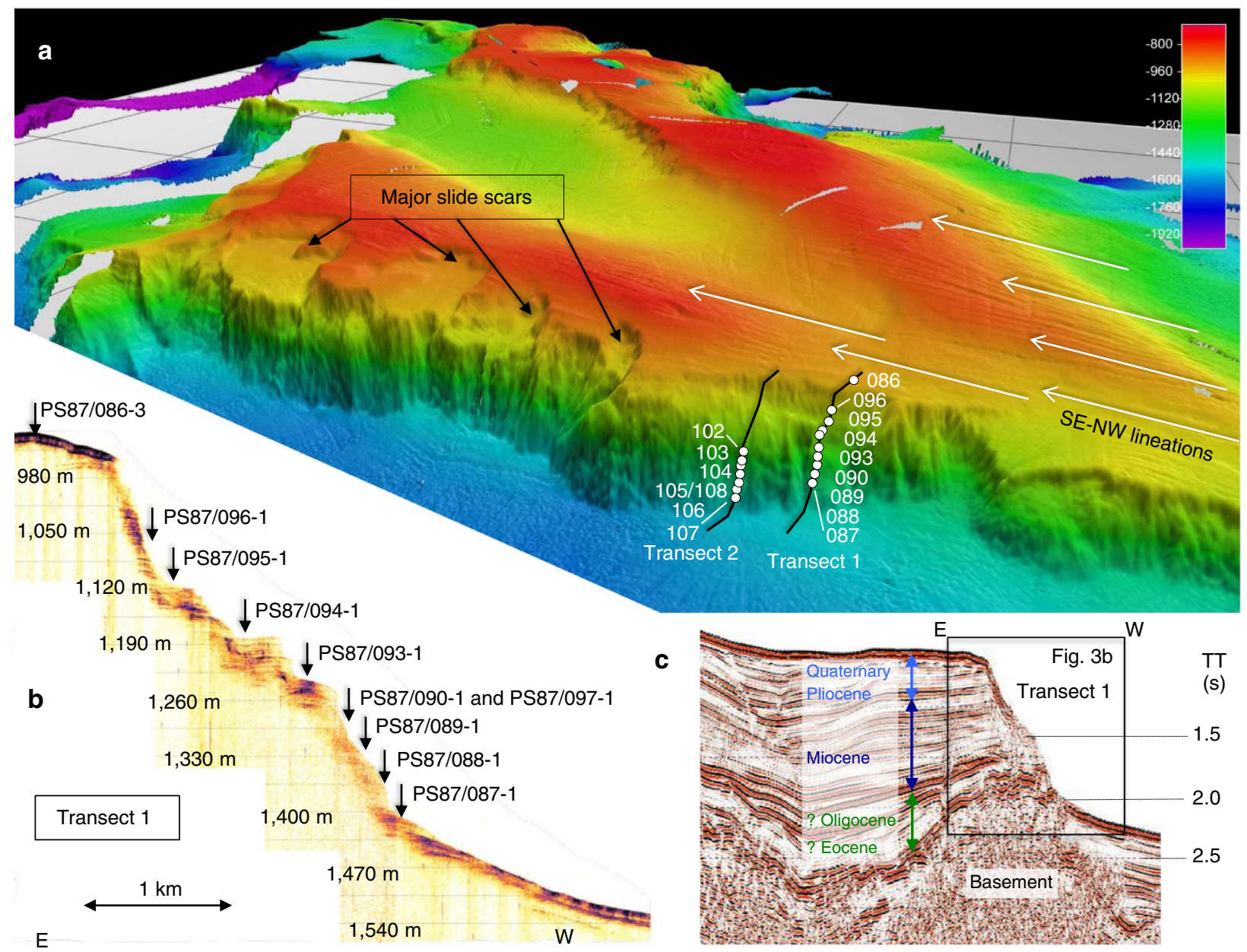

Figure 3 | Bathymetric and acoustic/seismic profiling records from southern Lomonosov Ridge. (a) Three-dimensional (3D) image of the swath bathymetry of southern Lomonosov Ridge, showing major slide scars and escarpments, streamlined SE-NW oriented glacial lineations formed beneath grounded ice sheets/streams and transects 1 and 2 with locations of sediment cores (cf., Supplementary Table 1). (b) PARASOUND profile across Transect 1 with locations of coring stations. (c) Processed multi-channel seismic profile AWI-20140311 across Transect 1, showing prominent reflectors and age assigments based on correlation between regional seismic lines and well data 22,23 . 
coring from Polarstern, rather than expensive drilling. The PARASOUND and MCS profiles suggest that these sedimentary sections are composed of Eocene, Oligocene, Miocene, Pliocene and Quaternary strata (Fig. 3b,c). The age control for the stratigraphic units is based on links of seismic lines to drill site data from the Chukchi Shelf, the ACEX drill site on central Lomonosov Ridge and onshore geology from the New Siberian Islands ${ }^{22,23}$. After evaluation of the multibeam bathymetry and PARASOUND data, we selected two transects across the steep western slope of Lomonosov Ridge for an extensive sediment coring programme (Fig. 3a, Transect 1 and Transect 2). In total, 16 sediment cores were recovered from water depths between $900 \mathrm{~m}$ (top of Lomonosov Ridge) and $1,500 \mathrm{~m}$ (foot of Lomonosov Ridge) ${ }^{17}$ (Fig. 3a,b and Supplementary Table 1).

Whereas most of the sediment cores of Transect 1 are composed of predominantly upper Quaternary (post slide) deposits, some contain prominent unconformities with lower/pre-Quaternary sediments underneath (see Methods and
Supplementary Figs 1 and 2). At these unconformities, a 50- to 80-m-thick overburden has been removed, as demonstrated in compaction experiments (see 'Sediment load and compaction experiments'). Unfortunately, the microfossil assemblages (that is, palynomorphs and agglutinated benthic foraminifers) do not allow a precise age determination of the sediments underlying the Quaternary near-surface deposits in most of these cores (Supplementary Table 1). The predominance of Quaternary sediments in the cores of Transect 1, however, seems to be supported by the biomarker composition determined in selected cores. Close to zero concentrations or the absence of specific biomarkers indicative for phytoplankton and sea-ice algae productivity point to surface-water conditions similar to those of the central Arctic Ocean during late Quaternary times ${ }^{16}$, characterized by a thick perennial sea-ice cover and SSTs $\ll 0^{\circ} \mathrm{C}$ (Supplementary Table 2 and Fig. 1).

The only core providing a clear indication that old sediments are cropping out near the seafloor is Core PS87/106. In this core

a Core PS87/106-1 WBD $\left(\mathrm{gcm}^{-3}\right)$

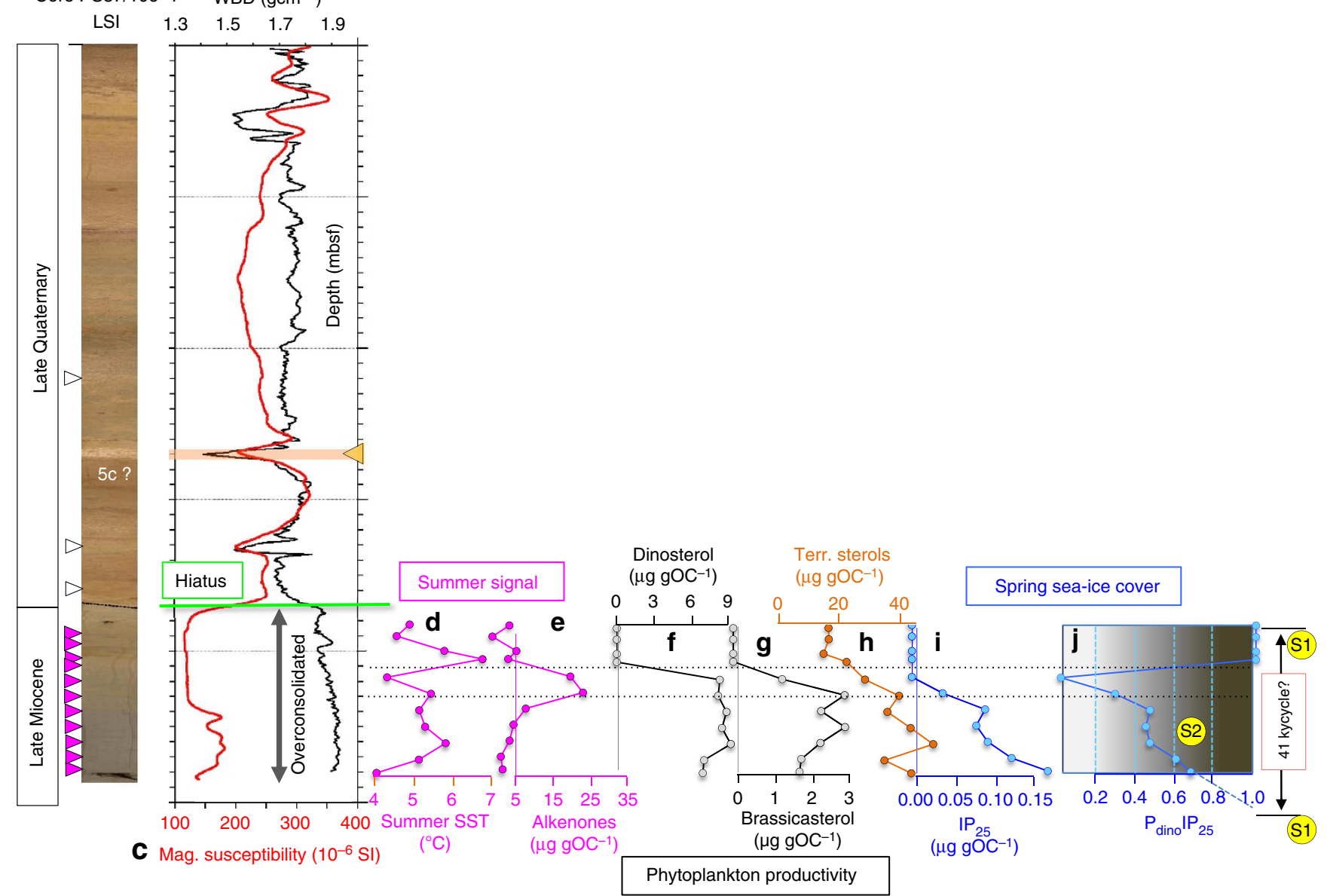

Figure 4 | Proxy evidence from Core PS87/106 for late Miocene Arctic Ocean climate conditions. (a) Line-scan image (LSI), (b) WBD, (c) MS, (d) alkenone-based SST, (e) concentrations of alkenones, (f) dinosterol and ( $(\mathbf{g})$ brassicasterol as proxy for primary productivity, (h) concentrations of terrigenous sterols (sum of campesterol and $\beta$-sitosterol), (i) concentrations of sea-ice proxy $\mathbb{P}_{25}$ and $\left(\mathbf{j}\right.$ ) sea-ice index $P_{\text {dino }} \mid P_{25}$ (for data see Supplementary Table 2). Purple and open triangles indicate the presence or absence of alkenones, respectively. Green line marks depth of the hiatus. Below the hiatus, sediments are overconsolidated. Zero or near-zero concentrations of $\mathrm{IP}_{25}$ and phytoplankton biomarkers are indicative for a closed (spring) sea-ice cover $\left(P_{\text {dino }} \mid P_{25}\right.$ is indetermable and set to ' 1 '; see Fig. 1 and Methods for further details). PIP 25 values are used to identify low (0-20\%), common (20-50\%), ice-edge (50-70\%) and extended (>70\%) sea-ice concentrations (see Fig. 1). The section below the hiatus represents about one cold ('glacial')-warm ('interglacial') cycle. S1 and S2 indicate two scenarios of different sea-ice concentrations (that is, maximum and transitional/stable ice edge, respectively) within this climate cycle. The interval between the two dashed horizontal lines marks period with minimum sea-ice cover. Using mean sedimentation rates of $\sim 3.2 \mathrm{~cm} \mathrm{ky}^{-1}$ (as calculated independently from close-by gravity cores ${ }^{50}$ and seismic data ${ }^{51}$ ), the duration of the climate cycle is $\sim 40 \mathrm{ky}$. 
recovered at the lower slope at Transect 2 (Fig. 3a), a sharp unconformity or hiatus occurs at $370 \mathrm{cmbsf}$. This unconformity is characterized by a marked change in colour, an abrupt increase in wet-bulk density (WBD; related to enhanced sediment consolidation underneath the hiatus), a significant drop in magnetic susceptibility (MS) and a major change in the biomarker composition, and it separates this interval from the overlying young and unconsolidated (upper Quaternary) sediments (Fig. 4 and Supplementary Table 2). The common occurrence of the acritarch Decahedrella martinheadii clearly indicates a late Miocene age for the lower part of the sedimentary sequence (Supplementary Fig. 3). The co-occurrence of the dinoflagellate cyst Nematosphaeropsis labyrinthus in combination with the absence of the Batiacasphaera micropapillata complex, however, may suggest a placement of the PS87/106 sediments within the upper part of its stratigraphic range, that is, upper Tortonian to lower Messinian, when compared with IODP/ACEX Hole M2A and ODP Hole $907 \mathrm{~A}^{24-27}$. Reworking of these late Miocene palynomorphs is excluded due to excellent preservation of the encountered delicate palynomorph specimens (see Methods for details of the age model of Core PS87/106).

Late Miocene SST and sea-ice records. The biomarker data of Core PS87/106 suggest significantly different late Miocene paleoenvironmental conditions in comparison with those predominant during Quaternary times (Fig. 4 and Supplementary Table 2). In the upper Miocene sediments, elevated concentrations of alkenones and alkenone-derived SST between 4 and $7^{\circ} \mathrm{C}$ (or even $6-9{ }^{\circ} \mathrm{C}$ in case other calibrations are used; $c f$. Supplementary Table 2) indicate relatively warm, open-water and productive paleoenvironmental conditions in the central Arctic Ocean during the summer season. This is also supported by SST values of $\gg 0^{\circ} \mathrm{C}$ determined in some samples from the ACEX Site (Supplementary Tables 2 and 3).

Our results reveal for the first time the occurrence of the biomarker sea-ice proxy $\mathrm{IP}_{25}$ in sediments as old as late Miocene. This proxy was developed by Belt et al. ${ }^{10}$ and was before our study only found in Quaternary and Pliocene sediments ${ }^{12,13}$. The presence of $\mathrm{IP}_{25}$ in the PS87/106 sediments is indicative for the presence of (spring) sea ice in the late Miocene central Arctic Ocean (Fig. 1). In comparison with $\mathrm{IP}_{25}$ values from the Arctic Ocean surface sediments ${ }^{16}$ and sediment trap data ${ }^{28}$, the absolute $\mathrm{IP}_{25}$ concentrations ranging between 0.05 and $0.15 \mu \mathrm{ggOC}^{-1}$ (Fig. 4 and Supplementary Table 2) are more than one order of magnitude lower. These differences are caused by an early degradation of biomarkers that already starts in the water column and reaches its maximum in the uppermost centimetres of the sediments ${ }^{28,29}$. On the other hand, both $\mathrm{IP}_{25}$ and phytoplankton biomarker concentrations determined in Core PS87/106 are in the same range than those determined in early-mid Holocene Arctic sediments ${ }^{8,30}$.

Using the 'PIP 25 Index' as a more semi-quantitative proxy of paleo-sea-ice cover (see Fig. 1 and Methods), our data from Core PS87/106 point to a variable spring sea-ice coverage of $\sim 20-70 \%$ in the lower part and $\sim 100 \%$ in the upper part of the sequence

a

Late Miocene: seasonal cycle at location of core PS87/106

(Scenario 2: 'transitional')

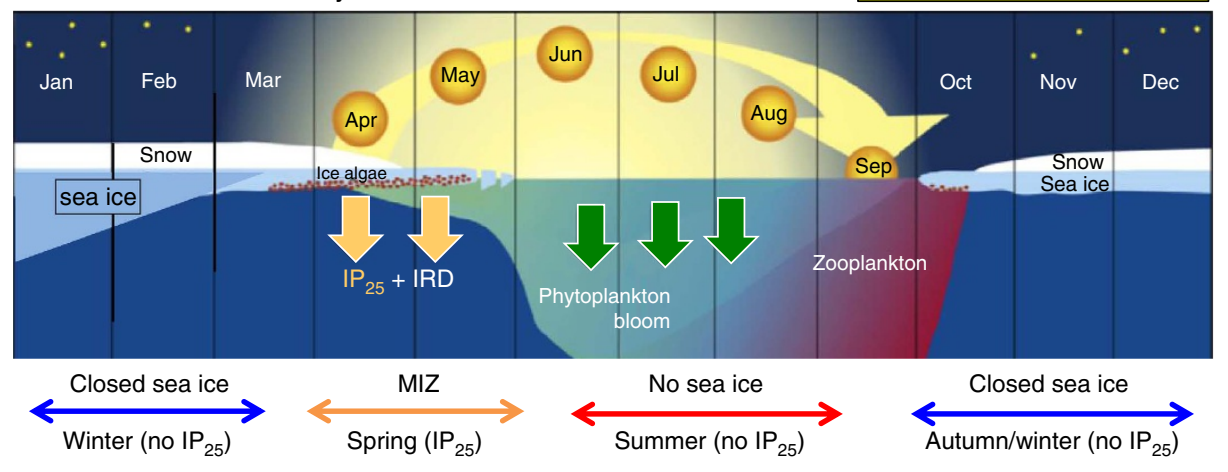

b

Late Miocene: seasonal cycle at location of core PS87/106

(Scenario 1: 'cold')

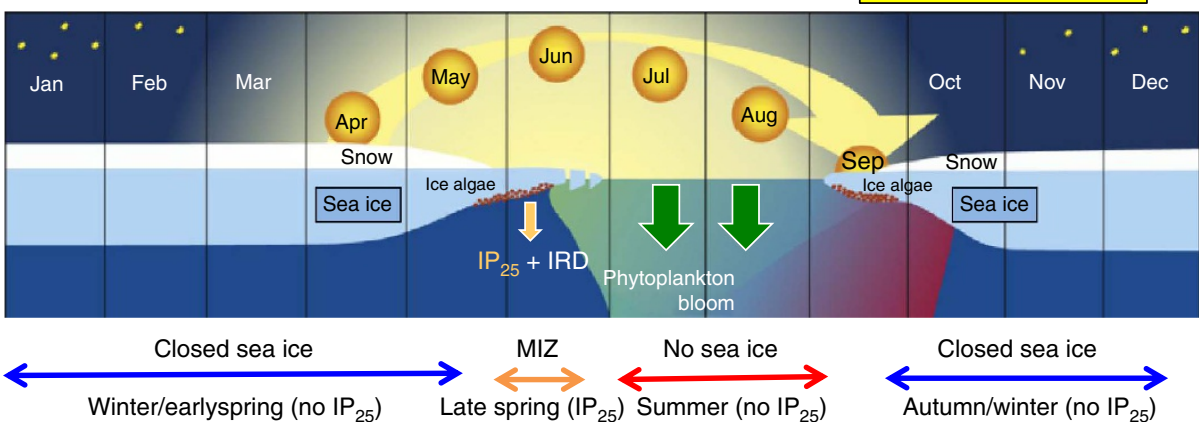

Figure 5 | Schematic illustrations of the seasonal sea-ice cycle during the late Miocene. The seasonal sea-ice cycle and related principal processes controlling productivity and carbon flux at location of central Arctic Ocean Core PS87/106 during the late Miocene are shown for two different scenarios. (a) Scenario 2 ('warmer/transitional situation') = extended period of spring sea-ice algae productivity and increased $\mathrm{IP}_{25}$ and phytoplankton biomarker fluxes. (b) Scenario 1 ('cold situation') = restricted period of late spring sea-ice algae productivity and very reduced fluxes (almost to zero) of $I_{25}$ and spring phytoplankton biomarkers; cf., Fig. 1). MIZ, Marginal Ice Zone, that is, ice-edge situation. The dark period, height of the sun and changing thickness of snow and ice over the year, as well as phytoplankton, zooplankton and sea-ice productivity are shown. $\mathrm{IP}_{25}$ values for the different seasons are indicated (after ref. 72, supplemented). 


\begin{tabular}{|c|c|c|}
\hline \multicolumn{3}{|c|}{ Late Miocene Arctic Ocean sea-ice concentration } \\
\hline March & June & September \\
\hline
\end{tabular}

$\mathrm{CO}_{2}$ level 450 p.p.m.

a
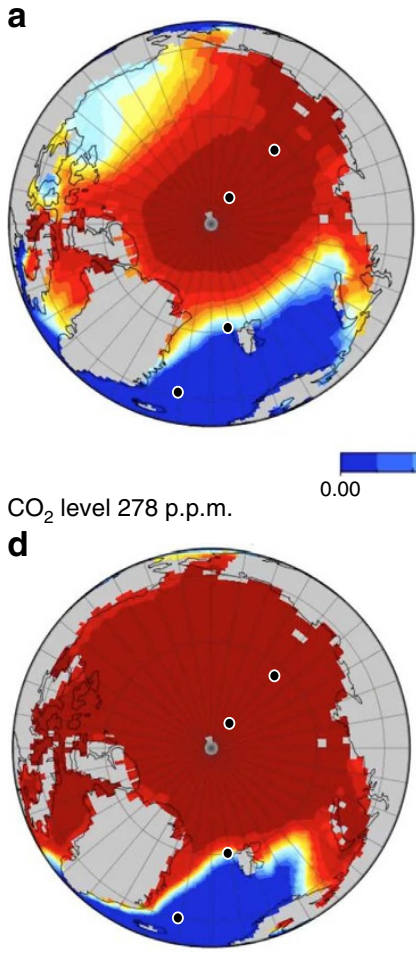

b

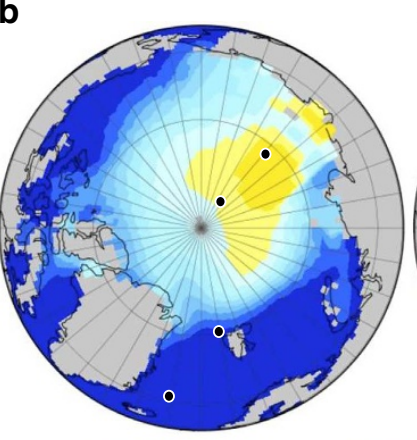

C

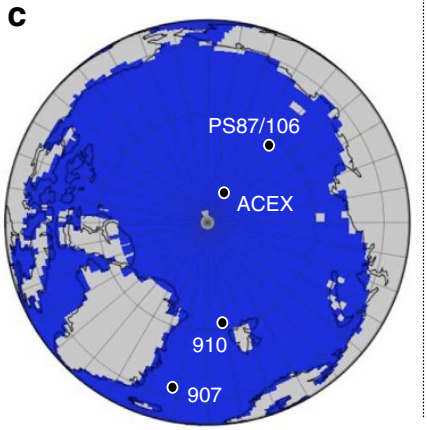

g

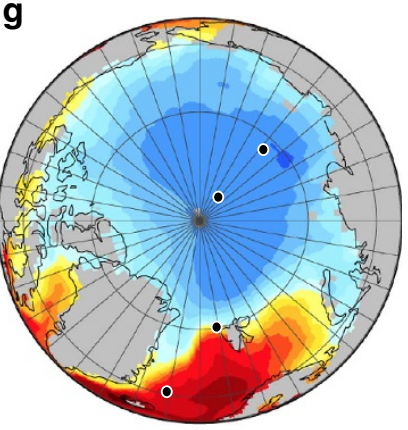

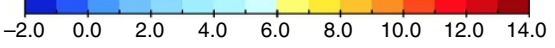

e

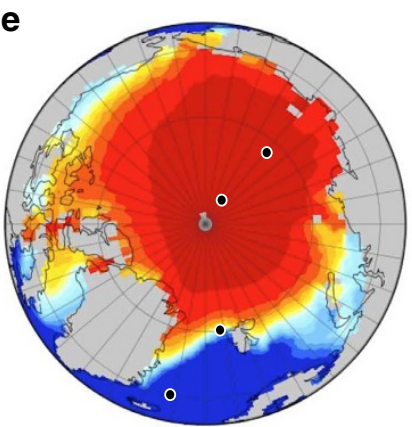

$\mathbf{f}$

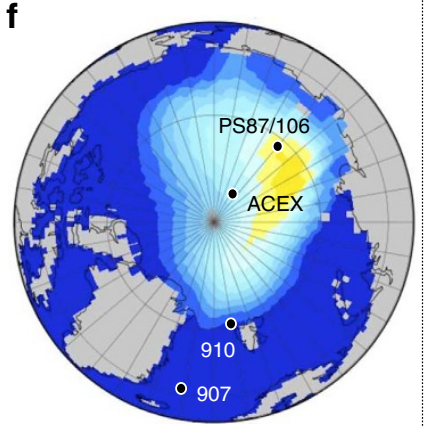

h

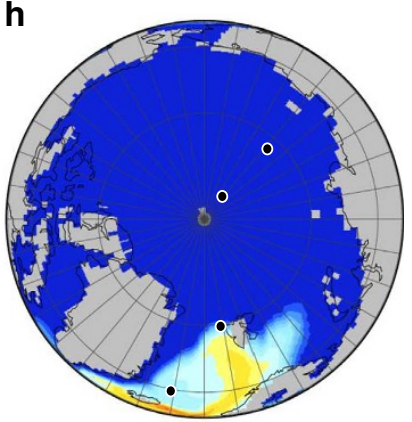

Figure 6 | Late Miocene Arctic Ocean climate simulations for high and low $\mathrm{pCO}_{2}$ levels using a coupled atmosphere-ocean general circulation model. (a-c,d-f) Sea-ice concentrations for March, June and September at 450 and 278 p.p.m. $\mathrm{CO}_{2}$ levels, respectively ${ }^{32}$. (g,h) Late Miocene August SST at 450 and 278 p.p.m. $\mathrm{CO}_{2}$ levels, respectively.

(Fig. 4). The combination of $\mathrm{IP}_{25}$ and SST data indicates that the central Arctic Ocean must have been relatively warm and ice-free during summer throughout the time interval recovered in the sedimentary section of Core PS87/106 and variable sea ice must have existed during spring when daylight conditions allowed sea-ice algae production (Figs 1 and 5, and Supplementary Table 2). Furthermore, this implies the presence of an extended sea-ice cover during the dark, cold winter season. These new data clearly support that periods with only a seasonal sea-ice coverage must have occurred in the central Arctic Ocean during most of the late Miocene (Fig. 5; see further discussion below).

Simulations of late Miocene Arctic Ocean climate. Model simulations of global climate conditions reconstructing a warm late Miocene climate apply atmospheric $\mathrm{CO}_{2}$ concentrations in the range of 280-700 p.p.m. ${ }^{31-34}$. Different reconstructions of late Miocene $\mathrm{CO}_{2}$ levels have narrowed the uncertainties, with atmospheric $\mathrm{CO}_{2}$ values likely to be below the present day concentrations ${ }^{35,36}$. Nevertheless, the associated uncertainties in the late Miocene $\mathrm{CO}_{2}$ levels are at least 200 p.p.m. ${ }^{34,37,38}$. Therefore, we have re-analysed Miocene climate simulations ${ }^{32,39}$ with $\mathrm{CO}_{2}$ concentrations of 278 and 450 p.p.m. using a coupled AOGCM. The investigation focus is on seasonal changes in the central Arctic Ocean as simulated with the AOGCM $^{32,39}$ (for details and background, see Methods).

Our simulated mean August SST and mean sea-ice concentrations for March, June and September/August for high (450 p.p.m.) and low (278 p.p.m.) $\mathrm{CO}_{2}$ levels (Fig. 6 and Supplementary Table 4) indicate the following: (1) a winter season with a closed sea-ice cover in the central Arctic Ocean decreasing towards the marginal seas for 450 p.p.m. $\mathrm{CO}_{2}$ (Fig. 6a) and a closed sea-ice cover in the entire Arctic Ocean including the marginal seas for 278 p.p.m. $\mathrm{CO}_{2}$ (Fig. 6d); (2) spring season sea-ice concentrations of $20-60 \%$ for 450 p.p.m. $\mathrm{CO}_{2}$ (Fig. 6b) and even $80-90 \%$ for 278 p.p.m. $\mathrm{CO}_{2}$ (Fig. 6e); and (3) a summer season with ice-free conditions and SSTs $>0{ }^{\circ} \mathrm{C}$ for 450 p.p.m. $\mathrm{CO}_{2}$ (Fig. 6c,g) and a reduced but still present sea-ice cover of $10-50 \%$ and SSTs $<-1{ }^{\circ} \mathrm{C}$ for 278 p.p.m. $\mathrm{CO}_{2}$ (Fig. 6f,h).

The AOGCM-based monthly mean sea-ice concentrations for 450 and 278 p.p.m. $\mathrm{CO}_{2}$ levels for late Miocene and preindustrial conditions at the ACEX, PS87/106, ODP 910 and ODP 907 sites are shown in Fig. 7 and-together with SST values-listed in Supplementary Table 4. Based on these results, the central Arctic Ocean was more or less ice free during summer and autumn (that is, between mid-June to mid-November) for 450 p.p.m. $\mathrm{CO}_{2}$, whereas sea ice still existed during summer times for 278 p.p.m. $\mathrm{CO}_{2}$ simulations. At the location of ODP Site 907, ice-free conditions occurred throughout the year for both simulations. In addition to the late Miocene and preindustrial simulations, future monthly mean sea-ice concentrations for AD 2100 and AD 2200 (following the Intergovernmental Panel on Climate Change medium stabilization scenario RCP4.5) (ref. 40) are shown (Fig. 7). These simulations suggest that the summer sea-ice concentrations will become significantly reduced to $20-40 \%$ during the next two centuries.

In combination with our new SST and sea-ice proxy data, these results suggest that either late Miocene $\mathrm{CO}_{2}$ levels have been relatively high or, alternatively, the applied model has an overly weak sensitivity especially in the northern high latitudes, as in the 

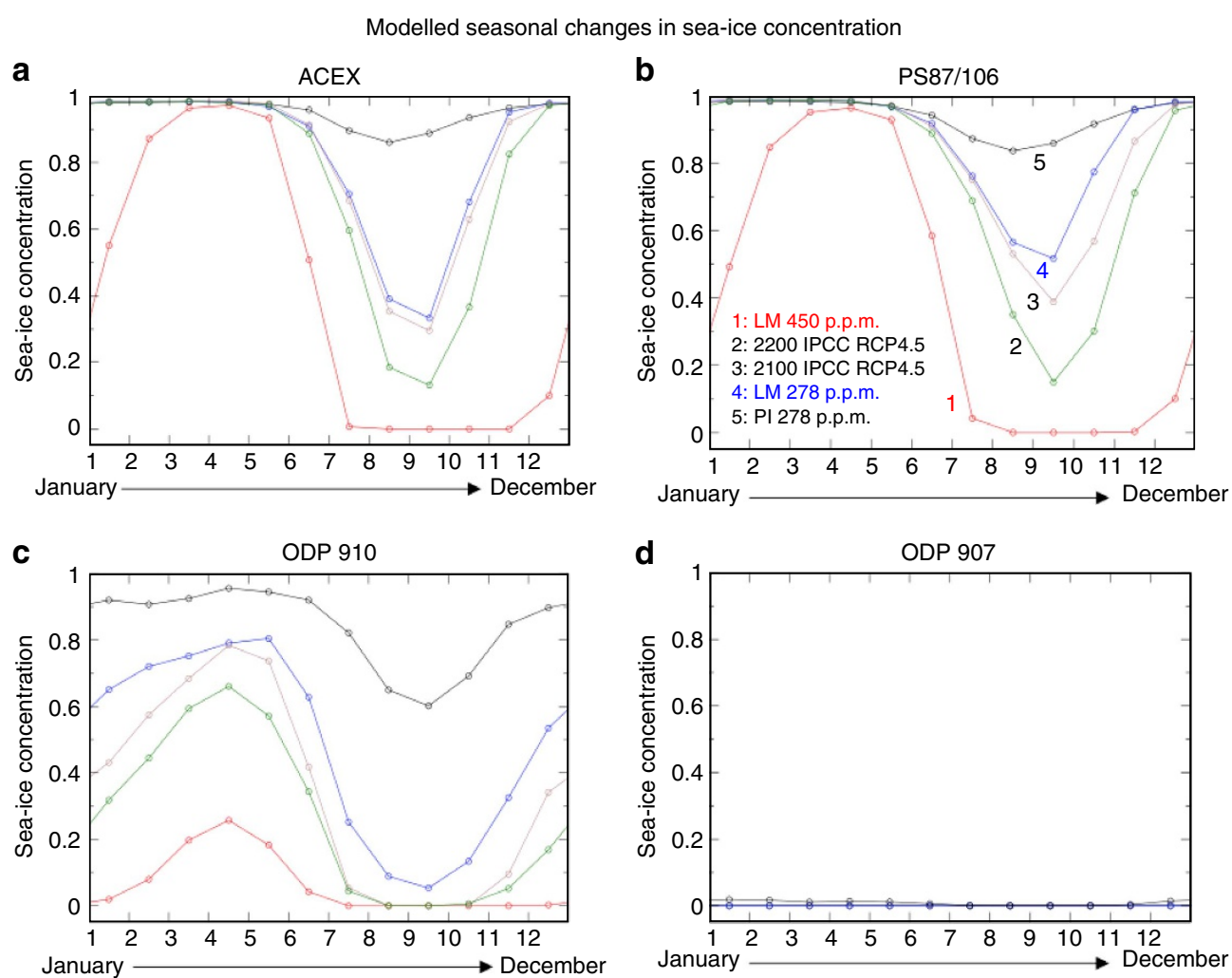

Figure 7 | Modelled monthly sea-ice concentration at the four different core locations. (a) ACEX Site, (b) Core PS87/106, (c) ODP Site 910 and (d) ODP Site 907. Climatological monthly mean sea-ice concentrations for late Miocene conditions with atmospheric $\mathrm{CO}_{2}$ concentrations of 450 p.p.m. (red curve) and 278 p.p.m. (blue curve), modelled sea-ice concentration for preindustrial conditions (black curve) with an atmospheric $\mathrm{CO}_{2}$ concentration of 278 p.p.m. ${ }^{32}$, as well as future conditions (monthly mean 2,085-2,115, brown curve; monthly mean 2,185-2,215, green curve) following the Intergovernmental Panel on Climate Change (IPCC) medium stabilization scenario RCP4.5 (Gierz et al. ${ }^{40}$ ) are shown.

simulation with a relatively low $\mathrm{CO}_{2}$ level of 278 p.p.m. summer SSTs are too low to explain our sedimentary SST proxy indicative of $4-7^{\circ} \mathrm{C}$. (Fig. 4 and Supplementary Tables 3 and 4). The latter reflects a characteristic challenge of current model approaches to simulate warm climates in the geological past ${ }^{41,42}$. Hence, the new findings from the Arctic region provide an enhanced basis for groundtruthing global climate reconstruction and modelling.

\section{Discussion}

Late Miocene climatic conditions significantly warmer than today have been reconstructed from marine and terrestrial proxy records from different localities around the globe ${ }^{43-47}$. However, quantitative SST proxy data from the High Arctic are exclusively restricted to a few terrestrial records 48,49 . With our study, we show for the first time that the late Miocene central Arctic Ocean was relatively warm with SSTs of $\sim 5^{\circ} \mathrm{C}$ (Figs 4 and 8) and icefree during summer, whereas sea ice occurred during spring and autumn/winter. During the late Miocene a general cooling trend is obvious as recorded in the SST record of the sub-Arctic ODP Site 907 (Fig. 8 and Supplementary Table 5). Such a cooling trend seems to be supported by the limited number of SST values available from the ACEX site (Fig. 8). Comparing this general cooling trend with the SST values from Core PS87/106, the sedimentary section of Core PS87/106 below the hiatus probably represents a time span within the upper Tortonian to lower Messinian as supported by palynomorph stratigraphy (Fig. 8). Furthermore, the new Arctic SST data fit in very well with the grander long-term Cenozoic cooling pattern (see Supplementary Fig. 4 and references in the figure legend).

Although on a first view this short sedimentary section of Core PS87/106 only represents a short snapshot of late Miocene Arctic climate, more detailed information about the late Miocene climate on a regional to even global scale can be obtained from our record. Based on the biomarker data, the 1.3-m-thick late Miocene section of Core PS87/106 probably represents almost one cycle with extended and reduced spring sea-ice conditions (Fig. 4). The (almost) absence of phytoplankton biomarkers and $\operatorname{IP}_{25}\left(\mathrm{PIP}_{25}=\right.$ ' 1 '; see Fig. 1$)$ and low concentrations of terrigenous biomarkers may be explained by an extended to closed sea-ice cover and a very restricted spring season (Scenario 1 in Figs 4 and 5). Scenario 2, on the other hand, represents a transitional phase with a stable ice edge during an extended and productive spring season, characterized by maximum input of phytoplanktion biomarkers and $\mathrm{IP}_{25}$ (resulting in $\mathrm{PIP}_{25}$ values of $0.4-0.7$ ), as well as maximum input of terrigenous biomarkers (and ice-rafted debris (IRD)) (Scenario 2 in Figs 4 and 5). The interval between scenarios 1 and 2 is characterized by very low to zero $\mathrm{IP}_{25}$ concentrations and increased concentrations of phytoplankton biomarkers, resulting in a distinct PIP $_{25}$ minimum (Fig. 4). This interval is interpreted as a period of minimum spring sea-ice extent. Furthermore, maximum values of alkenones may reflect increased productivity of haptophyte algae during the summer season.

Using mean sedimentation rates of $\sim 3.2 \mathrm{~cm} \mathrm{ky}^{-1}$ as calculated independently from close-by gravity cores ${ }^{50}$ and seismic data ${ }^{51}$, the duration of this cycle is about $40 \mathrm{ky}$, that is, very similar to the 41 ky obliquity cycle (Fig. 4 and also see ref. 52 and references therein). Hence, our record may represent just one obliquity cycle with ice-free conditions during summers in both the cold ('glacial') and the warm ('interglacial') phase of this climate cycle (Figs 4 and 5). As Core PS87/106 probably is of upper Tortonian to lower Messinian age (see above), 


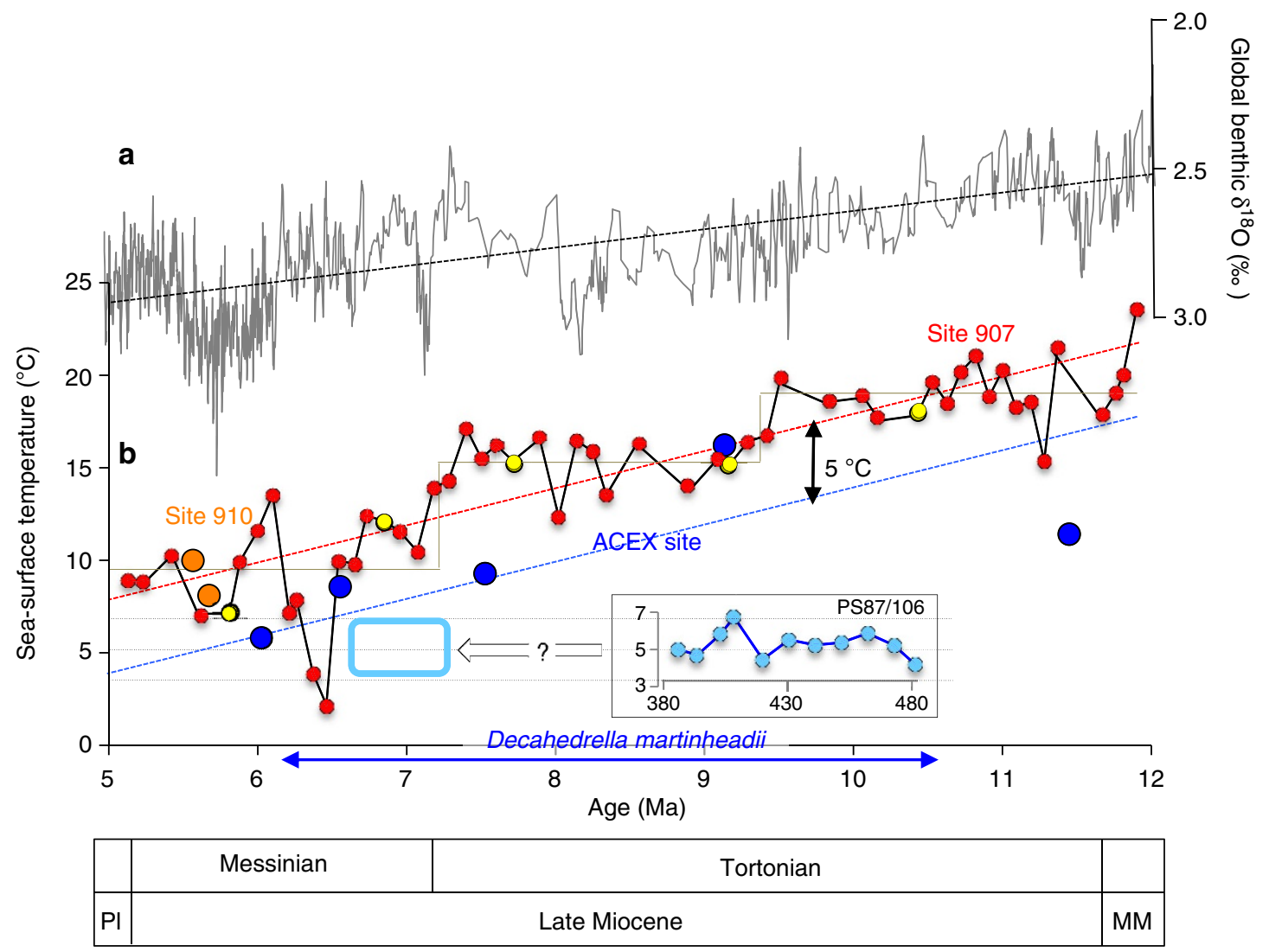

Figure 8 | Global climate (benthic $\boldsymbol{\delta}^{\mathbf{1 8}} \mathbf{0}$ ) stack and (sub-) Arctic SST records for the Late Miocene time interval. (a) Global benthic $\delta^{18} \mathrm{O}$ stack from ref. 43. (b) Late Miocene (Messinian/Tortonian) alkenone-based $U^{k^{\prime}}{ }_{37}$-SST of Site 907 (yellow circles) ${ }^{27}$ and this study (red circles; Supplementary Table 5), TEX ${ }_{86}$-SST values of Site 910 (orange circles) ${ }^{12}$ and alkenone-based $U^{k^{\prime}}{ }_{37}$-SST of the ACEX Site (blue circles; this study/Supplementary Table 2). The ages of the five ACEX samples are based on ${ }^{10} \mathrm{Be}$ stratigraphy ${ }^{73}$. General cooling trends in the 907 SST record (stippled red line), the ACEX SST record (stippled blue line, assuming a parallel SST trend to Site 907 with an offset of about $5^{\circ} \mathrm{C}$ ) and the benthic $\delta^{18} \mathrm{O}$ record (stippled black line) are indicated. The alkenone-based $U^{k^{\prime}}{ }_{37}$-SST of Core PS87/106 are plotted versus depth (centimetres below seafloor) (cf., Supplementary Table 2). The stratigraphic range of the acritarch D. martinheadii in the sub-Arctic/Arctic realm is indicated 24,25 . As the central Arctic Ocean ACEX and the PS87/106 SST values should be similar, the PS87/106 record probably repesents a time span within the upper Tortonian to lower Messinian (light blue box). PI, Pliocene; MM, Middle Miocene.

ice-free summer conditions should have occurred in the central Arctic Ocean during the warmer Middle Miocene to early Late Miocene time interval a fortiori (Fig. 8). In contrast to several previous studies, we therefore propose that a seasonal sea-ice cover was predominant in the central Arctic Ocean during (most of) the late Miocene time interval (see discussion below).

Our new semi-quantitative sea-ice and SST records are an important contribution to the ongoing and controversial debate about the reconstruction of the early (pre-Quaternary) Arctic Ocean sea-ice cover. Within this debate, the distinction between seasonal and perennial sea ice is critical, because year-round sea ice in the central Arctic implies very different climate feedback mechanisms, that is, Earth's albedo and heat exchange conditions, than an environment with ice-free conditions during summer. As outlined above, our new proxy data and modelling data clearly indicate a late Miocene seasonal sea-ice cover. Similar or even warmer climatic conditions also occurred in the Middle Miocene Arctic Ocean when looking at the alkenone-based summer SSTs of $10-13{ }^{\circ} \mathrm{C}$ reconstructed from ACEX sediments (Supplementary Fig. 4 and also see ref. 53). Abundant marine palynomorphs and foraminifers found in Miocene and early Pleistocene sediments of the ACEX section also point to at least periods with seasonally ice-free conditions ${ }^{24,54}$. These data are in contrast to an Arctic Ocean perennial sea-ice cover from middle Miocene onwards, as proposed by Darby ${ }^{55}$ and Krylov et al. ${ }^{56}$ based on their provenance studies of IRD in ACEX sediments. Taking the IRD with a North American or East Siberian origin found in the ACEX sediments and using modern sea-ice drift trajectories and velocities, these authors concluded that more than 1 year was needed to transport the sediments entrained in the sea ice to the ACEX location. Hence, the sea ice must have survived the summer melting season to reach the ACEX site.

Using a 'coupled sea-ice slab-ocean model including sediment transport by sea ice', Tremblay et al. ${ }^{57}$ have most recently demonstrated that sea-ice drift was probably significantly faster under warmer climatic conditions with less or much thinner sea ice than today. They conclude that the presence of ice-rafted sediment of Eurasian and North American origin at the North Pole is not a definite indication of a perennial sea ice cover in the Arctic Ocean. This may demonstrate that the main assumption of Darby $^{55}$ and Krylov et al. ${ }^{56}$ should be regarded critically.

Our proxy and model reconstruction of late Miocene Arctic climate is certainly a substantial step forward to improve the understanding of the pre-Quaternary Arctic Ocean sea-ice and SST history. However, to decipher the pre-Quaternary climate history of this unique and sensitive but still not well-known region on Earth in more detail, long continuous sedimentary records to be obtained only by scientific drilling are needed. These records are planned to be recovered within a new IODP drilling campaign scheduled for 2018 (IODP Proposal 708; http:// 
www.iodp.org/expeditions). Based on the new PS87 seismic data, $\sim 200 \mathrm{~m}$ of Plio-Pleistocene, $>600 \mathrm{~m}$ of Miocene and $>300 \mathrm{~m}$ of Oligocene-Eocene may be recovered at the proposed drill sites ${ }^{51}$ (see Fig. 2 for locations). The outcome of such a new programme will certainly help to improve our understanding of the complex ocean-atmosphere-ice system in the polar high northern latitudes and its role in the past, modern and future global climate.

\section{Methods}

Shipboard surveys and measurements. The methods used on board Polarstern during Expedition PS87 are shortly outlined in the following. For a more detailed information about the use and interpretation of the proxy data we refer to the different chapters of the Cruise Report ${ }^{17}$.

The bathymetric survey was performed using the hull-mounted ATLAS Hydrographic HYDROSWEEP DS3, a deep-sea multi-beam swath sonar system with a resolution of up to 320 receive beams per ping, a swath width of 4-5 times the water depth and a vertical resolution of $\sim 0.5 \%$ of the water depth. It was operated in the chirp mode with a frequency of $14-16 \mathrm{kHz}$. The mean sound velocity of the water column was calculated from conductivity-temperature-density (CTD), expandable CTD (XCTD) and Valeport Sound Velocity Profiler data.

Sub-bottom profiling data were acquired using the parametric hull-mounted system ATLAS Hydrographic PARASOUND DS III-P70. Primary operating frequencies were 18.75 and $22.95 \mathrm{kHz}$ with a secondary sediment-penetrating frequency of $4.2 \mathrm{kHz}$, a beam angle of $4^{\circ}$ and a pulse length of 2 . The vertical resolution is $\sim 0.2 \mathrm{~m}$. As a result of the narrow beam angle, reflections from strata dipping by $>4^{\circ}$ cannot be received by the vessel. This explains why the thin veneer of post-slide sediments covering the slump scar is not resolved as it is above and below the headwall (Fig. 3b). The headwall has an inclination $>4^{\circ}$. In contrast, the older (pre-Quaternary) sediments exhibit nearly horizontal bedding (Fig. 3), which are thus acoustically resolved along the headwall to their near-seafloor location. PARASOUND data visualization and processing was performed using ATLAS PARASTORE-3 software. The vertical scale on profiles has been converted from travel time to metres using a constant sound velocity of $1.5 \mathrm{~km} \mathrm{~s}^{-1}$, which explains minor differences in water depth between PARASOUND and swath-sonar data.

For the MCS data acquisition, a 3,000-m-long streamer (240 active channels, group interval of $12.5 \mathrm{~m}$ ) and an air gun array of four G-Guns (total volume of $32 \mathrm{l}$, fired with 200 bar every $15 \mathrm{~s}$ ) were used. Processing included sorting, that is, common depth point sorting with $25 \mathrm{~m}$ spacing, frequency filtering $(20-180 \mathrm{~Hz})$, velocity analysis, multiple suppression and stacking.

Whole-core measurements included non-destructive, continuous determinations of core geometry (diameter), WBD, P-wave velocity $(V \mathrm{p})$ and loop-sensor MS at $10 \mathrm{~mm}$ intervals, using a standard Multi-Sensor Core Logger (GEOTEK Ltd., UK). The principle of logging cores is described in more detail in the GEOTEK manual 'Multi-Sensor Core Logging', which can be downloaded from the web (http://www.geotek.co.uk).

Line-scan images (Supplementary Figs 1 and 2) were acquired with a Jai CV L107 camera with RGB (red-green-blue) channels at 630, 535 and $450 \mathrm{~nm}$, respectively, mounted to an Avaatech XRF core scanner. The camera contains three charge-coupled device sensors and a beam splitter to separate the RGB signal. Images were acquired with a down-core resolution of $\sim 70 \mu \mathrm{m}$.

Stratigraphic framework and marine palynology process. The general lithostratigraphic framework and age model of the upper Quaternary sedimentary sections recovered during Expedition PS87 are robust and based on lithostratigraphy, colour imaging, WBD and MS records characterized by very prominent minima and maxima, and correlation with other dated sediment cores from Lomonosov Ridge ${ }^{17,50}$. Based on this concept, MIS 6 to 1 were identified in most of the cores (Supplementary Fig. 1). Some cores from very steep sections of the slope along Transect 1 (Fig. 3b), on the other hand, contain multiple unconformities and a correlation to the reference Core PS87/086 was only partly possible

(Supplementary Fig. 2). WBD typically increases sharply below the unconformities due to higher degrees of compaction, supporting a hiatus and 'older' sediments below (Supplementary Fig. 2). For this study dealing with the late Miocene climate history, only the identification and dating of these 'older' (Neogene) sedimentary sections are relevant. For assessing the age of these sediments, assemblages of agglutinated benthic foraminifers and palynomorphs were used and compared with biostratigraphic records obtained from the ACEX and North Atlantic sites ${ }^{17,24-27}$ (Supplementary Table 1).

For sample preparation and processing of the agglutinated benthic foraminifers we refer to the PS87 Cruise Report ${ }^{17}$ and further references therein. The procedure for studying the palynomorphs are as follows: dinoflagellate cysts and acritarchs were investigated in 25 samples (mainly core catcher) from 15 cores recovered along transects 1 and 2 (Fig. $3 \mathrm{a}$ and Supplement Table 1), with special emphasis on Core PS87/106. Sediment was freeze dried, weighed and processed using standard palynological maceration techniques including repeated treatment with cold $\mathrm{HCl}$ (10\%) and cold HF (38-40\%), no oxidation and sieving over a $10-\mu \mathrm{m}$-nylon mesh. The residue has been mounted with glycerine jelly on microscope slides, which were then scanned for dinoflagellate cysts and acritarchs using a light microscope at $\times 400$ original magnification.

Age model of the late Miocene section of core PS87/106. Based on microfossil data (that is, palynomorphs and agglutinated benthic foraminifers), the core catcher samples from the sediment cores were barren or give a Pleistocene age (Supplementary Table 1). The only core providing any clear indication that old sediments are cropping out in the shallow sub-seafloor is Core PS87/106. Well-preserved specimens of organic-walled palynomorphs (dinoflagellate cysts and acritarchs) have been recorded in successive samples from the base of the core (including core catcher) up to $420 \mathrm{cmbsf}$ (that is, $50 \mathrm{~cm}$ below the hiatus; Supplementary Table 1). Of the encountered species, the acritarch D. martinheadii provides evidence that the lower part of the core is composed of sediments of late Miocene age. This species is endemic to the high northern latitudes and its stratigraphic range has been discussed previously based on comprehensive reviews of its occurrence at several DSDP, ODP and IODP sites from the Central Arctic Ocean, Norwegian-Greenland Sea, Labrador Sea, Baffin Bay and Irminger Sea ${ }^{24-26}$ It is restricted to the late Miocene in the Arctic and subarctic realm, and based on the pristine paleomagnetic record of Iceland Sea ODP Site 907, its stratigraphic range is independently calibrated against the astronomically tuned Neogene Timescale, thus providing absolute age control (Supplementary Fig. 3). A nearsynchronous highest occurrence at ca. 6.3-6.2 Ma has been defined from several northern high latitude sites, suggesting this species to be an excellent marker across the subpolar/polar North Atlantic and Arctic Ocean ${ }^{25}$. In addition, a highest common occurrence is recognized at $6.5 \mathrm{Ma}$ in Iceland Sea ODP Hole 907A and more generally at $c a$. 6.7-6.3 Ma across the Norwegian-Greenland Sea. The lowest occurrence of D. martinheadii has been calibrated to $10.5 \mathrm{Ma}$ in ODP Hole 907. According to Schreck et al. ${ }^{25}$, however, the lowest occurrence is not very well constrained at other sites but certainly younger than $11 \mathrm{Ma}$ across the northernmost North Atlantic and Arctic Ocean.

In Core PS87/106, the consistent occurrence of $D$. martinheadii is accompanied by low numbers of the dinoflagellate cyst $N$. labyrinthus. Such co-occurrence has also been observed within the upper part of its stratigraphic range in IODP Hole M2A $\mathrm{A}^{24}$ and ODP Hole 907 (refs 25,27). Furthermore, the B. micropapillata complex has not been recorded in PS87/106 samples. This dinoflagellate cyst dominates assemblages in the late Serravallian of IODP/ACEX Hole M2A, decreases significantly across the Tortonian and disappears close to the Tortonian/ Messinian boundary ${ }^{26}$. In ODP Hole 907A, B. micropapillata complex dominates the assamblage until $c a$. $8.2 \mathrm{Ma}$ after which it only occurrs sporadically until its highest common occurrence at $c a .4 .5 \mathrm{Ma}^{26,27}$. Therefore, the co-occurrence of $D$. martinheadii and $N$. labyrinthus in combination with the absence of B. micropapillata complex may allow to place the analysed interval of Core PS87/106 into the upper Tortonian to lower Messinian. However, we note that the highest occurrence derived from ODP Site 907 may represent a minimum age for this bioevent in the Central Arctic Ocean, as successive Neogene cooling may led to an earlier disappearance of species in the higher latitudes.

$D$. martinheadii and $N$. labyrinthus are both very delicate species that bear processes and trabeculae (ribbon-like bars), which tend to crumple easily. All specimens encountered during palynological analyses, however, are well preserved indicating in situ deposition.

Biomarker analyses. Extraction of 5-10 g of freeze-dried sediments was carried out using an accelerated solvent extractor (DIONEX, ASE200; $100^{\circ} \mathrm{C}, 5 \mathrm{~min}$, $1,000 \mathrm{psi})$ with dichloromethane:methanol $(2: 1, \mathrm{v} / \mathrm{v})$ as the solvent. For quantification internal standards, 7 -hexylnonadecane $(7-\mathrm{HND}, 0.076 \mu \mathrm{g}$ per sample for $\mathrm{IP}_{25}$ quantification), squalane $\left(2.4 \mu \mathrm{g}\right.$ per sample) and cholesterol- $\mathrm{d}_{6}$ (cholest-5-en$3 \beta$-ol- $\mathrm{D}_{6}, 10 \mu \mathrm{g}$ per sample for sterol quantification) were added before analytical treatment. Separation of the hydrocarbon and sterol fractions was carried out via open column chromatography (hydrocarbon fraction with $5 \mathrm{ml} n$-hexane, the sterol fraction with $6 \mathrm{ml} n$-hexane:ethylacetate $(5: 1, \mathrm{v} / \mathrm{v}))$. The latter fraction was silylated with $500 \mathrm{ml}$ BSTFA (bis-trimethylsilyl-trifluoroacet-amide) $\left(60^{\circ} \mathrm{C}, 2 \mathrm{~h}\right)$. $\mathrm{IP}_{25}$ and sterols were analysed by gas chromatography (GC)/mass spectrometry. Component assignment was based on comparison of GC retention times with those of reference compounds and published mass spectra (Supplementary Figs 5 and 6). The Kovats Index calculated for $\mathrm{IP}_{25}$ is 2,086. For the monounsaturated HBI alkene (HBI monoene) most recently found in ancient Arctic sediments and characterized by very similar chromatographic and mass spectral properties ${ }^{58}$, the Kovats Index has been calculated as 2,090. As this new HBI monoene is absent in the investigated cores of this study, we have calculated the index from lower Pliocene sediment samples from ODP Site 911 to show that both compounds can clearly be separated by our analytical approach (see Supplementary Fig. 5a,b). The detection limit for quantification of $\mathrm{IP}_{25}$ (Agilent 7890B GC, Agilent 5977A Extractor MSD with Performance Turbo Pump) is $0.005 \mathrm{ng}^{-1}$ in SIM (selected ion monitoring) mode. To obtain mass spectra in TIC (total ion current) the limit is $0.05 \mathrm{ng}^{-1}$. The retention indices for brassicasterol (as 24-methylcholesta-5,

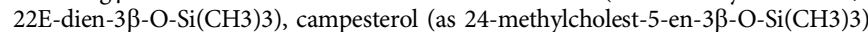
and $\beta$-sitosterol (as 24-ethylcholest-5-en-3 $\beta$-O-Si $(\mathrm{CH} 3) 3$ ) were calculated to be $1.018,1.042$ and 1.077 (normalized to cholest-5-en-3 $\beta-$ ol- $\mathrm{D}_{6}$ set to be 1.000 ), respectively.

For the quantification of $\mathrm{IP}_{25}$, its molecular ion $(\mathrm{m} / z$ 350) in relation to the abundant fragment ion $\mathrm{m} / z 266$ of the internal standard (7-HND) was used 
(SIM mode). The different responses of these ions were balanced by an external calibration (Supplementary Fig. $5 \mathrm{c}$ and also see ref. 28). Brassicasterol (24-methylcholesta-5,22E-dien-3 $\beta$-O-Si $\left.\left(\mathrm{CH}_{3}\right)_{3}\right)$, campesterol (24-methylcholest5-en-3 3 -O-Si $\left.\left(\mathrm{CH}_{3}\right)_{3}\right)$ and $\beta$-sitosterol (24-ethylcholest-5-en-3 $\beta$-O-Si $\left(\mathrm{CH}_{3}\right)_{3}$ ) were quantified as trimethylsilyl ethers using the molecular ions $\mathrm{m} / \mathrm{z} 470, \mathrm{~m} / \mathrm{z} 472$ and $\mathrm{m} / z 486$, respectively, in relation to the molecular ion $\mathrm{m} / z 464$ of cholesterol- $\mathrm{D}_{6}$.

More details about the identification and quantification of $\mathrm{IP}_{25}$ and the sterols are described elsewhere ${ }^{8,28,29,58-61}$

For more semi-quantitative estimates of the present and past sea-ice coverage, Müller et al. ${ }^{14}$ combined the sea-ice proxy $\mathrm{IP}_{25}$ and phytoplankton biomarkers in a phytoplankton-IP ${ }_{25}$ index, the so-called 'PIP ${ }_{25}$ index' (Fig. 1):

$$
\mathrm{PIP}_{25}=\left[\mathrm{IP}_{25}\right] /\left(\left[\mathrm{IP}_{25}\right]+([\text { phytoplanktonmarker }] \times \mathrm{c})\right)
$$

with $c=$ mean $\mathrm{IP}_{25}$ concentration/mean phytoplankton biomarker concentration for a specific data set or core. As phytoplankton biomarkers brassicasterol and dinosterol were used, resulting in $\mathrm{P}_{\text {bras }} \mathrm{IP}_{25}$ and $\mathrm{P}_{\text {dino }} \mathrm{IP}_{25}$ values, respectively (see refs 8,16,29,59 for discussion of advantages and limitations of the PIP $_{25}$ approach). Most recently, Smik et al. ${ }^{62}$ introduced a HBI-III alkene as phytoplankton biomarker replacing the sterols in the $\mathrm{PIP}_{25}$ calculation. This modified $\mathrm{PIP}_{25}$ approach is far less dependent on the balance factor $c$ and based on biomarkers from the same group of compounds (that is, HBIs) with more similar diagenetic sensitivity, certainly an important improvement for paleo-sea-ice reconstructions and comparison of records from different Arctic areas.

Our reconstruction of SST is based on long-chain $\mathrm{C}_{37}$ alkenones synthesized by

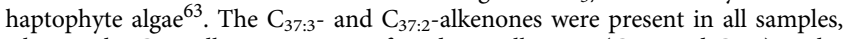
whereas the $\mathrm{C}_{37 \cdot 4}$-alkenone was not found. For alkenone $\left(\mathrm{C}_{37 \cdot 2}\right.$ and $\left.\mathrm{C}_{37 \cdot 3}\right)$ analysis, extraction of additional $6 \mathrm{~g}$ of freeze-dried sediment was carried out using the ASE method under same conditions as decribed above but with dichloromethane as the solvent. The separation of compounds was carried out by open column chromatography using $5 \mathrm{ml} n$-hexane, followed by $5 \mathrm{ml} n$-hexane:dichloromethane $(1: 1, \mathrm{v} / \mathrm{v})$ and $5 \mathrm{ml}$ dichloromethane for eluation of the alkenones. As internal standard $n$ - $\mathrm{C}_{36: 0}(10 \mu \mathrm{g}$ per sample) was added before any analytical treatment. The alkenones were analysed by GC. Individual alkenone $\left(\mathrm{C}_{37: 3}\right.$ and $\left.\mathrm{C}_{37: 2}\right)$ identification is based on retention time and the comparison with an external standard (Supplementary Fig. 7). To exclude a possible coeluation of the alkenones with other compounds, the extracts were measured first as total extract, second after additional column cleaning with dichloromethane and third after saponification ${ }^{64}$. The instrument stability has been continuously controlled by re-runs of an external alkenone standard (extracted from cultures of Emiliania huxleyi with known growth temperature) during the analytical sequences. The range of the total analytical error calculated by replicate analyses is $<0.4{ }^{\circ} \mathrm{C}$.

For calculation of SST, we used the simplified $U_{37}^{K^{\prime}} \operatorname{Index}^{63}$ :

$$
U k_{37}^{\prime}=C_{37.2} /\left(C_{37.2}+C_{37.3}\right)
$$

$U_{37}^{K^{\prime}}$ was converted to SST according to the World Ocean core top versus annual temperature calibration $\left(U_{37}^{K^{\prime}}=0.033 \mathrm{~T}+0.044\right)$ (ref. 64), the calibration most often used in the literature. Resulting SSTs vary between 4.2 and $6.7^{\circ} \mathrm{C}$ (SST-1; Fig. 4 and Supplementary Table 2). For the central Arctic Ocean, these SSTs certainly have to be interpreted as summer SSTs (instead of annual mean) due to the darkness during late autumn to winter (cf., Fig. 5). In addition, we also have used the Müller et al. ${ }^{64}$ calibration versus summer SST (SST-2), the Sikes et al. ${ }^{65}$ calibration versus summer SST obtained from the polar Southern Ocean (SST-3) and the Prahl and Wakeham ${ }^{63}$ calibration obtained from cultural experiments (SST-4). Whereas the SST-4 values are more or less the same as the SST-1 values, the SST-2 and SST-3 values (calculated as 'summer SST') are higher and vary between 6 and $9^{\circ} \mathrm{C}$ (Supplementary Table 2). Based on these results, we interpret our late Miocene summer SSTs of $\sim 4-7^{\circ} \mathrm{C}$ (mean of $5.3^{\circ} \mathrm{C}$ ) more as minimum values. For the Müller et al..$^{64}$ calibration, the standard error is reported as \pm 0.050 $U_{37}^{K^{\prime}}$ units or $\pm 1.5^{\circ} \mathrm{C}$ for the entire temperature range from 0 to $27^{\circ} \mathrm{C}$. In the lower temperature range $<10^{\circ} \mathrm{C}$, however, the scatter of the $U_{37}^{K^{\prime}}$ values is significantly higher than the mean. Thus, one should not overinterpret the SST variability between 4 and $7{ }^{\circ} \mathrm{C}$. In any case and independently of the calibration approach, summer SSTs were significantly higher than zero, preventing sea-ice formation during summer.

The results of the biomarker analyses (that is, alkenones, selected sterols, SSTs, $\mathrm{IP}_{25}$ and PIP ${ }_{25}$ ) carried out on samples from various PS87 sediment cores, are listed in Supplementary Table 2. All biomarker data (expressed in $\mathrm{gg} \mathrm{gOC}^{-1}$ and $\mu \mathrm{ggSediment}{ }^{-1}$ ) are available online at http://dx.doi.org/10.1594/ PANGAEA.855509.

Model simulation. For the investigation of the late Miocene Arctic climatic conditions (that is, climatological sea-ice cover and SST) we have re-analysed Miocene climate simulations ${ }^{32,39}$. The simulations have been performed with a coupled AOGCM. The atmosphere model component ECHAM5 (ref. 66) was used at T31 resolution $\left(\sim 3.75^{\circ}\right)$ with 19 vertical levels. The ocean component MPI-OM ${ }^{67}$, including the dynamics of sea ice formulated using viscous-plastic rheology ${ }^{68}$, has an average horizontal resolution of $3^{\circ} \times 1.8^{\circ}$ with 40 uneven vertical layers. This modelling approach has been used and evaluated for investigations of the Miocene climate ${ }^{32,39}$. For the re-analyses, we have used data from two model runs with the same late Miocene set-up ${ }^{32}$, except different atmospheric $\mathrm{CO}_{2}$ concentrations. One simulation is based on a $\mathrm{CO}_{2}$ concentration of 278 p.p.m. ${ }^{32}$ and one uses a $\mathrm{CO}_{2}$ concentration of 450 p.p.m. ${ }^{39}$. For further details of the AOGCM model configuration and the boundary conditions, we refer the reader to refs 32,39 .

Sediment load and compaction experiments. The preconsolidation stress of a geological sample experienced in the past can be assessed by incrementally loading the specimen in a uniaxial deformation apparatus (so-called 'oedometer'), where deviations in the settling behaviour can be converted to the thickness of the missing overburden. We used this approach to estimate the thickness of sediment removed at prominent unconformities observed in some of our studied sediment cores (Fig. 4 and Supplementary Figs 2 and 8 ).

We conducted our experiments using a combined GIESA oedometer-direct shear apparatus in which both uniaxial compression tests and shear tests can be conducted in consecutive steps ${ }^{69}$ (Supplementary Fig. 8b). The sample cell is a cylindrical volume within a stack of two steel plates. If desired, relative displacement of the plates enforces simple shear deformation in the sample, to measure undrained shear strength. Porous metal frits allow fluid communication with an open pore fluid reservoir (containing distilled water) and dissipation of excess pore pressure. Normal load is applied to the sample with a vertical ram and shear is induced by holding the upper plate fixed, while the lower plate is driven horizontally.

For the experiments in this study, we only used the consolidation function of the system. As is done routinely in such tests ${ }^{70}$, we loaded each sample incrementally by starting with applied normal stresses of $10 \mathrm{kPa}$. This value was assumed to be below the in situ stress the samples had experienced before. After $24 \mathrm{~h}$, the normal load is doubled. Tests were run over many days until the desired maximum normal load was reached $(10,240 \mathrm{kPa}$ for Core PS87/096 and 5,120 $\mathrm{kPa}$ for Core PS87/106). The initial water content of each sample was taken from an aliquot before the specimen was mounted into the GIESA oedometer. We measured the wet weight of the aliquot, subjected it to $48 \mathrm{~h}$ of gentle drying in an oven $\left(60^{\circ} \mathrm{C}\right)$ and then measured the dry weight, to calculate the void ratio $e$ (where $e=$ volume of voids/volume of solids).

Oedometer results are plotted as effective normal stress versus void ratio, the latter of which is derived from the settling (that is, change in sample thickness as determined using a vertical displacement transducer) after each loading increment The graph of each experiment show a smooth function when $e$ is plotted against normal stress, the latter on a logarithmic axis (Supplementary Fig. 8c). In an undeformed sample, the regular loading results in the so-called 'virgin consolidation curve', whereas samples that were previously subject to loading usually deviate from the smooth curvature and show a distinct change in gradient of the graph. The high-stress end of the graph is generally linear and serves to assess the maximum preconsilidation stress the sample has experienced following the procedure first established by A. Casagrande ${ }^{69}$.

The stress measurements are then used to the thickness $(h)$ of the overburden based on the effective load $(h=$ preconsolidation stress/(bulk density of the sample - density of seawater) $\times g$ ). The degree of overconsolidation of a given sample is then calculated as the ratio between preconsolidation stress and normal stress at that depth below the seafloor.

We have tested one pair of samples in cores PS87/096 and PS87/106, respectively, and loaded these samples to at least $5,120 \mathrm{kPa}$ effective stress. Our results attest that the samples taken above the hiatuses are normally consolidated, while those underneath the discontinuity are overconsolidated. In Core PS87/096, the estimated preconsolidation stress below the hiatus is $590 \mathrm{kPa}$, which amounts to the removal of a 80-m-thick sediment package (Supplementary Fig. 8c). In Core PS87/106, the preconsolidation stress is between 320 and $480 \mathrm{kPa}$, which corresponds to 48 and $65 \mathrm{~m}$ of overburden, respectively (cf., Fig. 4).

For Core PS87/096, the calculated thickness of removed sediments are more or less identical to those estimated from the ages of the sediments above and below the hiatus (that is, $\sim 100 \mathrm{ka}$ and $<2.5 \mathrm{Ma}$, respectively) and mean sedimentation rate of $3.2 \mathrm{~cm} \mathrm{ky}^{-1}$ (refs 50,71), resulting in a maximum sediment removal of $80 \mathrm{~m}$ (Supplementary Fig. 8a).

\section{References}

1. ACIA Members. Arctic Climate Impact Assessment Report (Cambridge Univ. Press, 2005).

2. Stocker, T. et al. Climate Change 2013, The Physical Science Basis 1535 (Intergovernmental Panel on Climate Change (IPCC), Cambridge Univ. Press, 2013).

3. Stroeve, J., Holland, M. M., Meier, W., Scambos, T. \& Serreze, M. Arctic sea ice decline: faster than forecast. Geophys. Res. Lett. 34, L09501 (2007).

4. Backman, J., Moran, K., McInroy, D. B. \& Mayer, L. A.the Expedition 302 Scientists. Proceedings IODP 302 (Integrated Ocean Drilling Program Management International, College Station, 2006).

5. Moran, K. et al. The Cenozoic palaeoenvironment of the Arctic Ocean. Nature 441, 601-605 (2006).

6. Stein, R. et al. Cenozoic Arctic Ocean climate history: some highlights from the IODP Arctic Coring Expedition (ACEX). Dev. Marine Geol. 7, 259-293 (2014).

7. Thomas, D. N. \& Diekmann, G. S. Sea Ice (Blackwell Publishing, 2010).

8. Stein, R., Fahl, K. \& Müller, J. Proxy reconstruction of Arctic Ocean sea ice history: 'From IRD to $\mathrm{IP}_{25}$ '. Polarforschung 82, 37-71 (2012). 
9. De Vernal, A., Gersonde, R., Goosse, H., Seidenkrantz, M.-S. \& Wolff, E. W. Sea ice in the paleoclimate system: the challenge of reconstructing sea ice from proxies-an introduction. Quat. Sci. Rev. 79, 1-8 (2013).

10. Belt, S. T. et al. A novel chemical fossil of palaeo sea ice: IP25. Org. Geochem. 38, 16-27 (2007).

11. Brown, T. A., Belt, S. T., Tatarek, A. \& Mundy, C. J. 2014. Source identification of the Arctic sea ice proxy $\mathrm{IP}_{25}$. Nat. Commun. 5, 4197 (2014).

12. Knies, J. et al. The emergence of modern sea ice cover in the Arctic Ocean. Nat. Commun. 5, 1-5 (2014).

13. Stein, R. \& Fahl, K. Biomarker proxy $\mathrm{IP}_{25}$ shows potential for studying entire Quaternary Arctic sea-ice history. Org. Geochem. 55, 98-102 (2013).

14. Müller, J. et al. Towards quantitative sea ice reconstructions in the northern North Atlantic: a combined biomarker and numerical modeling approach. Earth Planet. Sci. Lett. 306, 137-148 (2011).

15. Müller, J., Massé, G., Stein, R. \& Belt, S. T. Variability of sea-ice conditions in the Fram Strait over the past 30,000 years. Nat. Geosci. 2, 772-776 (2009).

16. Xiao, X., Fahl, K., Müller, J. \& Stein, R. Sea-ice distribution in the modern Arctic Ocean: biomarker records from Trans-Arctic Ocean surface sediments. Geochim. Cosmochim. Acta 155, 16-29 (2015).

17. Stein, R. (ed.). The Expedition PS87 of the Research Vessel Polarstern to the Arctic Ocean in 2014, Reports on Polar and Marine Research Vol. 688 (Alfred Wegener Institute for Polar and Marine Research. http://epic.awi.de/ 37728/1/BzPM_0688_2015.pdf, 2015).

18. Kristoffersen, Y., Coakley, B. J., Hall, J. K. \& Edwards, M. Mass wasting on the submarine Lomonosov Ridge, central Arctic Ocean. Mar. Geol. 243, 132-142 (2007).

19. Jakobsson, M. et al. Arctic Ocean glacial history. Quat. Sci. Rev. 92, 40-67 (2014).

20. Jakobsson, M. et al. An Arctic Ocean ice shelf during MIS 6 constrained by new geophysical and geological data. Quat. Sci. Rev. 29, 3505-3517 (2010).

21. Niessen, F. et al. Repeated Pleistocene glaciation of the East Siberian Continental Margin. Nat. Geosci. 6, 842-846 (2013).

22. Hegewald, A. \& Jokat, W. Tectonic and sedimentary structures in the northern Chukchi region, Arctic Ocean. J. Geophys. Res. 118, 3285-3296 (2013).

23. Weigelt, E., Jokat, W. \& Franke, D. Seismostratigraphy of the Siberian Sector of the Arctic Ocean and adjacent Laptev Sea Shelf. J. Geophys. Res. Solid Earth 119, 5275-5289 (2014).

24. Matthiessen, J., Brinkhuis, H., Poulsen, N. \& Smelror, M. Decahedrella martinheadii Manum 1997-a stratigraphicall and paleoenvironmentally useful Miocene acritarch of the high northern latitudes. Micropaleontology 55, 171-186 (2009)

25. Schreck, M., Matthiessen, J. \& Head, M. J. A magnetostratigraphic calibration of Middle Miocene through Pliocene dinoflagellate cyst and acritarch events in the Iceland Sea (Ocean Drilling Program Hole 907A). Rev. Palaeobot. Palynol. 187, 66-94 (2012)

26. Schreck, M. \& Matthiessen, J. in Biological and Geological Perspectives of Dinoflagellates. (eds Lewis, J., Marret, F. \& Bradley, L.) 301-314 (The Micropalaeontological Society, Special Publications: Geological Society, 2013).

27. Schreck, M., Méheust, M., Stein, R. \& Matthiessen, J. Response of marine palynomorphs to Neogene climate cooling in the Iceland Sea (ODP Hole 907A). Mar. Micropaleontol. 101, 49-67 (2013).

28. Fahl, K. \& Stein, R. Modern seasonal variability and deglacial/Holocene change of central Arctic Ocean sea-ice cover: new insights from biomarker proxy records. Earth Planet. Sci. Lett. 351-352C, 123-133 (2012).

29. Belt, S. T. \& Müller, J. The Arctic sea ice biomarker $\mathrm{IP}_{25}$ : a review of current understanding, recommendations for future research and applications in palaeo sea ice reconstructions. Quat. Sci. Rev. 79, 9-25 (2013).

30. Müller, J. et al. Holocene cooling culminates in sea ice oscillations in Fram Strait. Quat. Sci. Rev. 47, 1-14 (2012).

31. Micheels, A. et al. Analysis of heat transport mechanisms from a Late Miocene model experiment with a fully-coupled atmosphere-ocen general circulation model. Palaeogeogr. Palaeoclimatol. Palaeoecol. 304, 337-350 (2011).

32. Knorr, G., Butzin, M., Micheels, A. \& Lohmann, G. A warm Miocene climate at low atmospheric $\mathrm{CO}_{2}$ levels. Geophys. Res. Lett. 38, L20701 (2011).

33. Steppuhn, A. et al. The sensitivity of ECHAM4/ML to a double $\mathrm{CO}_{2}$ scenario for the Late Miocene and the comparison to terrestrial proxy data. Glob. Planet. Change 57, 189-212 (2007)

34. Bradshaw, C. D. et al. The relative roles of $\mathrm{CO}_{2}$ and palaeogeography in determining late Miocene climate: results from a terrestrial model-data comparison. Clim. Past 8, 1257-1285 (2012).

35. Beerling, D. J. \& Royer, D. L. Convergent Cenozoic $\mathrm{CO}_{2}$ history. Nat. Geosci. 4, 418-420 (2011).

36. Van de Wal, R. S. W., de Boer, B., Lourens, L. J., Köhler, P. \& Bintanja, R. Reconstruction of a continuous high-resolution $\mathrm{CO}_{2}$ record over the past 20 million years. Clim. Past 7, 1459-1469 (2011)

37. Breecker, D. O. \& Retallack, G. J. Refining the pedogenic carbonate atmospheric $\mathrm{CO}_{2}$ proxy and application to Miocene $\mathrm{CO}_{2}$. Palaeogeogr. Palaeoclimatol. Palaeoecol. 406, 1-8 (2014).
38. Zhang, Y. G., Pagani, M., Liu, Z., Bohaty, S. M. \& DeConto, R. A 40-millionyear history of atmospheric $\mathrm{CO}_{2}$. Phil. Trans. R. Soc. A 371, 20130096 (2013).

39. Knorr, G. \& Lohmann, G. Climate warming during Antarctic ice sheet expension at the Middle Miocene transition. Nat. Geosci. 7, 376-381 (2014).

40. Gierz, P., Lohmann, G. \& Wei, W. Response of Atlantic overturning to future warming in a coupled atmosphere-ocean-ice sheet model. Geophys. Res. Lett. 42, 6811-6818 (2015).

41. PALAEOSENS Project-Members. Making sense of palaeoclimate sensitivity. Nature 491, 683-691 (2012).

42. Huber, M. A sensitivity to history. Nat. Geosci. 6, 15-16 (2013).

43. Zachos, J. C., Dickens, G. R. \& Zeebe, R. E. An early Cenozoic perspective on greenhouse warming and carbon-cycle dynamics. Nature 451, 281-283 (2008).

44. LaRiviere, J. P. et al. Late Miocene decoupling of oceanic warmth and atmospheric carbon dioxide forcing. Nature 486, 97-100 (2012).

45. Zhang, Y. G., Pagani, M. \& Liu, Z. A 12-million-year temperature history of the tropical Pacific Ocean. Science 344, 84-87 (2014).

46. Pound, M. J. et al. A Tortonian (Late Miocene, 11.61-7.25 Ma) global vegetation reconstruction. Palaeogeogr. Palaeoclimatol. Palaeoecol. 300, 29-45 (2011).

47. Lunt, D. J. et al. A methodology for targeting palaeo proxy data aquisition: a case study for the terrestrial late Miocene. Earth Planet. Sci. Lett. 271, 53-62 (2008).

48. Wolfe, J. A. An analysis of Neogene climates in Beringia. Palaeogeogr. Palaeoclimatol. Palaeoecol. 108, 207-216 (1994).

49. Utescher, T., Bondarenko, O. V. \& Mosbrugger, V. The Cenozoic Cooling-continental signals from the Atlantic and Pacific side of Eurasia. Earth Planet. Sci. Lett. 415, 121-133 (2015).

50. Stein, R. et al. Accumulation of particulate organic carbon at the Eurasian continental margin during late Quaternary times: controlling mechanisms and paleoenvironmental significance. Glob. Planet. Change 31, 87-102 (2001).

51. Stein, R., Jokat, W., Niessen, F. \& Weigelt, E. Exploring the long-term Cenozoic Arctic Ocean Climate History-A challenge within the International Ocean Discovery Program (IODP). Arktos. doi:10.1007/s41063-015-0012-x (2015).

52. Tian, J., Yang, M., Lyle, M. W., Wilkens, R. \& Shackford, J. K. Obliquity and long eccentricity pacing of the Middle Miocene climate transition. Geochem. Geophys. Geosys 15, 1740-1755 (2013).

53. Weller, P. \& Stein, R. Paleogene biomarker records from the central Arctic Ocean (IODP Expedition 302): Organic-carbon sources, anoxia, and sea-surface temperature. Paleoceanography 23, PA1S17, doi:10.1029/ 2007PA001472 (2008).

54. Cronin, T. M., Smith, S. A., Eynaud, F., O’Regan, M. \& King, J. Quaternary paleoceanography of the central Arctic based on Integrated Ocean Drilling Program Arctic Coring Expedition 302 foraminiferal assemblages. Paleoceanography 23, PA1S18 (2008).

55. Darby, D. A. Arctic perennial ice cover over the last 14 million years. Paleoceanography 23, PA1S07, doi:10.1029/2007PA001479 (2008).

56. Krylov, A. A. et al. A shift in heavy and clay mineral provenance indicates a middle Miocene onset of a perennial sea-ice cover in the Arctic Ocean. Paleoceanography 23, PA1S06, doi:10.1029/2007PA001497 (2008).

57. Tremblay, L.-B., Schmidt, G. A., Pfirman, S., Newton, R. \& Derepentigny, P. Is ice-rafted sediment in a North Pole marine record evidence of perennial sea-ice cover? Phil. Trans. R. Soc. A A373, 20140168 (2015).

58. Cabedo-Sanz, P. \& Belt, S. T. Identification and characterisation of a novel mono-saturated highly branched isoprenoid (HBI) alkene in ancient Arctic sediments. Org. Geochem. 81, 34-39 (2015).

59. Belt, S. T. et al. Identification of paleo Arctic winter sea ice limits and the marginal ice zone: optimised biomarker-based reconstructions of late Quaternary Arctic sea ice. Earth Planet. Sci. Lett. 431, 127-139 (2015)

60. Belt, S. T. et al. A reproducible method for the extraction, identification and quantification of the Arctic sea ice proxy $\mathrm{IP}_{25}$ from marine sediments. Analyt. Methods 4, 705-713 (2012).

61. Belt, S. T. et al. An inter-laboratory investigation of the Arctic sea ice biomarker proxy $\mathrm{IP}_{25}$ in marine sediments: key outcomes and recommendations. Clim. Past Discuss. 10, 155-166 (2014).

62. Smik, L., Cabedo-Sanz \& Belt, S. T. Semi-quantitative estimates of paleo Arctic sea ice concentration based on source-specific highly branched isoprenoid alkenes: a further development of the PIP25 index. Org. Geochem. 92, 63-69 (2016).

63. Prahl, F. G. \& Wakeham, S. G. Calibration of unsaturation patterns in long-chain ketone compositions for palaeotemperature assessment. Nature $\mathbf{3 3 0}$ 367-369 (1987).

64. Müller, P. J., Kirst, G., Ruhland, G., von Storch, I. \& Rosell-Melé, A. Calibration of the alkenone paleotemperature index $U^{k}$-based on core-tops from the eastern South Atlantic and the global ocean (60 degrees N -60 degrees S). Geochim. Cosmochim. Acta 62, 1757-1772 (1998).

65. Sikes, E. L., Volkman, J. K., Robertson, L. G. \& Pichon, J.-J. Alkenones and alkenes in surface waters and sediments of the Southern Ocean: implications for paleotemperature estimation in polar regions. Geochim. Cosmochim. Acta 61, 1495-1505 (1997). 
66. Roeckner, E. et al. The atmospheric general circulation model ECHAM5. Part 1. Model description. Max Planck Inst. Meteorol. Rep. 349, ISSN 0937-1060 (2003).

67. Marsland, S. J., Haak, H., Jungclaus, J. H., Latif, M. \& Röske, F. The Max-Planck-Institute global ocean/sea ice model with orthogonal curvilinear coordinates. Ocean Model 5, 91-127 (2003).

68. Hibler, W. III. A dynamic thermodynamic sea ice model. J. Phys. Oceanogr. 9, 815-846 (1979)

69. Ikari, M. J. \& Kopf, A. J. Cohesive strength of clay-rich sediment. Geophys. Res. Lett. 38, L16309, 5 (2011).

70. Craig, R. F. Craig’s Soil Mechanics 446 (Spon Press, 1974).

71. Stein, R. Arctic Ocean Sediments: Processes, Proxies, and Palaeoenvironment 2, 587 (Elsevier, 2008).

72. Wassmann, P. Arctic marine ecosystems in an era of rapid climate change. Progr. Oceanography 90, 1-17 (2011).

73. Frank, M. et al. Beryllium isotopes in central Arctic Ocean sediments over the past 12.3 million years: stratigraphic and paleoclimatic implications. Paleoceanography 23, PA1S02, doi:10.1029/2007PA001478 (2008).

\section{Acknowledgements}

We gratefully thank Captain Schwarze and his crew of RV Polarstern for the excellen support and cooperation during the entire cruise. We thank the PS87 Geoscience Party for support in getting geophysical and geological shipboard data and sediments during the expedition (see 'Supplementary Note 1'). We thank three anonymous reviewers for numerous constructive suggestions for improvement of the manuscript. Thanks to Simon Belt (Biogeochemistry Research Centre, University of Plymouth/UK) for providing the 7-HND standard for $\mathrm{IP}_{25}$ quantification. This publication is a contribution to the Research Programme PACES II, Topic 3 (The earth system from a polar perspective: data, modelling and synthesis) of the Alfred Wegener Institute Helmholtz Centre for Polar und Marine Research (AWI). The study used samples and data provided by AWI (grant number AWI-PS87_01) and the IODP Program. This research is also supported by KOPRI's Basic Research Project (PE15062) and a National Research Foundation of Korea Grant funded by the Korean Government (2015M1A5A1037243).

\section{Author contributions}

R.S. and W.J. proposed the main research goals of the PS87 Expedition. R.S. was chief scientist of the PS87 Expedition and leader of the geology group, developed the lithostratigraphic framework of the PS87 sediment cores, and wrote the first draft of the manuscript. K.F. conducted all biomarker analyses, evaluation and quality control. M.S. and M.K. identified the assemblages of palynomorphs and benthic agglutinated foraminifers, respectively, used for biostratigraphy and age control. G.K. and G.L. developed the model and experimental design. G.K. carried out the experiments. F.N. compiled the physical property and PARASOUND data. L.J. aquired and processed multibeam bathymetry data. M.F. was responsible for XRF scanning and line-scan imaging of the sediment cores. J.M. led the offshore geological activities on deck and in the laboratories. W.J. led the offshore geophysical activities and data acquisition. C.G. processed the multi-channel seismic data. A.K. carried out the sediment load and compaction experiments. All authors contributed to the data interpretation and writing of the final version of the manuscript.

\section{Additional information}

Supplementary Information accompanies this paper at http://www.nature.com/ naturecommunications

Competing financial interests: The authors declare no competing financial interests.

Reprints and permission information is available online at http://npg.nature.com/ reprintsandpermissions/

How to cite this article: Stein, R. et al. Evidence for ice-free summers in the late Miocene central Arctic Ocean. Nat. Commun. 7:11148 doi: 10.1038/ncomms11148 (2016).

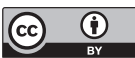

This work is licensed under a Creative Commons Attribution 4.0 International License. The images or other third party material in this article are included in the article's Creative Commons license, unless indicated otherwise in the credit line; if the material is not included under the Creative Commons license, users will need to obtain permission from the license holder to reproduce the material. To view a copy of this license, visit http://creativecommons.org/licenses/by/4.0/ 